WILLEM H. BUITER

University of Bristol and National Bureau of Economic Research

MARCUS MILLER

University of Warwick

\title{
The Thatcher Experiment: The First Two Years
}

The General Election of May 1979 in the United Kingdom ushered into power a Conservative administration whose monetary and budgetary policies differed quite markedly from those of its predecessors, both in objectives and in the means for achieving them. The macroeconomic objectives of the present government have been stated clearly. In a letter to the House of Commons Treasury and Civil Service Committee in February 1980, the Chancellor of the Exchequer wrote: "The main objectives of the Government's economic strategy are to reduce inflation and to create conditions in which sustainable economic growth can be achieved." It was also emphasized that, in contrast to previous Labour and Conservative administrations, the use of incomes policy was not viewed as the appropriate way to check inflation.

A central plank of the new government's platform was to strengthen the supply side of the economy. This was to be achieved through fiscal measures (primarily a switch from taxes on labor income to taxes on spend-

We benefited from discussions with John Flemming, statistical information from the National Institute of Economic and Social Research, and from constructive suggestions from members of the Brookings panel. W. Buiter is indebted to the Leverhulme Foundation for research support.

1. Memoranda on Monetary Policy and Public Expenditure, House of Commons Treasury and Civil Service Committee, sess. 1979-80 (London: Her Majesty's Stationery Office, 1980), pp. 3-5. 
ing and on oil rents and a reduction in public expenditure), by restoring "a broad balance of power in the framework of collective bargaining" (measures to remove specific abuses in picketing and the closed shop) and by other measures aimed at encouraging market forces to work as freely and flexibly as possible (such as the abolition of price, dividend, and exchange controls). Privatization of some nationalized industries and a general reduction in industrial intervention were also on the agenda. Bringing down the rate of inflation was seen as a precondition for a return to higher employment. The short-term stabilization of output, employment, and external current account was deliberately de-emphasized.

The policy of the Thatcher government was revealed clearly in the two budgets enacted in the first year of office. The Conservative party had promised to reduce the "standard rate" of income tax in its election campaign, and this commitment was promptly fulfilled in its first budget of June 1979 when the standard rate was reduced by 3 percentage points. ${ }^{3}$ The top rate was also reduced from 83 to 60 percent and the tax brackets considerably widened. However, to offset the impact on the budget deficit of these tax cuts aimed at the supply side, the rate of indirect taxation was increased, with the standard rate of value added tax rising from 8 percent to 15 percent and the rate on luxuries from $12 \frac{1}{2}$ percent to 15 percent. In a bold gesture the government also abolished exchange, dividend, and price controls in its first budget.

The government also "rolled forward" the money-supply targets that it had inherited from the previous Labour government. The target range for the growth of the broad money supply, sterling M3, was reduced from 8 to 12 percent to 7 to 11 percent at an annual rate.

Another inheritance from the Labour government that the Thatcher administration did not abandon was the commitment to implement wage settlements determined by the Pay Comparability Commission for certain employees in the public sector: the rate of these settlements, together with those for other public sector employees, led to an increase of earnings in the public sector that was to total 25 percent over the year to 1980:3. With the retail price index rising by 4 percentage points as a direct result of the indirect tax increases in the budget, settlements in the private sector

2. Ibid., p. 5 .

3. The standard rate is the initial marginal rate of income tax, which persists over a wide range of income; this rate stood at 33 percent when the government came into office. 
continued at a rapid pace, with the basic weekly wage rate for manual workers increasing by 19.2 percent in the year to $1980: 3$, for example.

The government renounced all recourse to incomes policies as a way of heading off the inflationary surge. Instead, in its second budget of March 1980 it chose to launch what was called the medium-term financial strategy (MTFS). This consisted of a four-year declining target path for the growth of a broad monetary aggregate (sterling M3) and a supporting path for the public sector borrowing requirement (PSBR) which, among other features, involved a progressive decline of the government's deficit relative to GDP. While annual monetary targets had been in operation in the United Kingdom since December 1976, the MTFS did constitute a major innovation. In a memorandum to the Treasury Committee, the Treasury explained: "The Government has deliberately not set its targets in terms of the ultimate objectives of price stability and high output and employment because these are not within its direct control. It has instead set a target for the growth of money supply, which is more directly under its influence, and has stated that it will frame its policies for taxation and public expenditure to secure a deceleration of money supply without excessive reliance on interest rates."

This, then, was Prime Minister Margaret Thatcher's experiment: the rate of wage settlements would be determined by market forces operating within a framework of demand-management policies that were to achieve a particular intermediate nominal objective announced in advance; the operation of market forces was to be assisted by policies reducing the rate of direct taxation and the volume of government spending-measures it was hoped would favorably affect the supply side of the economy. The combination of real output growth and wage-price inflation that might emerge in attaining the nominal target was to be left for forces within the economy to determine. ${ }^{5}$

4. Memoranda on Monetary Policy, House of Commons Treasury and Civil Service Committee, sess. 1979-80, vol. 2 (HMSO, 1980), p. 9.

5. The strategy is not unlike the "credible threat" strategy advocated for the United States by William Fellner in "The Valid Core of Rationality Hypotheses in the Theory of Expectations," Journal of Money, Credit and Banking, vol. 12, pt. 2: "Rational Expectations" (November 1980), pp. 763-87. Thus far, the Fellner strategy has not been fully embraced in the United States. Unlike Mrs. Thatcher, President Reagan has not publicly committed his government to pursue relentlessly a policy of steady monetary disinflation. 
The immediate and thus far main result of the Thatcher policies has been a major loss of competitiveness accompanied by a large decline in production and rise in unemployment - a slump so severe we refer to it as a depression. After an initial increase, the rate of inflation has come down steadily and has stabilized recently at about 11 percent a year. Any positive supply-side effects that may have resulted from the government's fiscal measures are both hard to identify because of the slump in output and employment and unlikely to be exploited as long as the depression lasts.

To understand the genesis of the depression it is necessary to recognize the importance for the transmission mechanism of monetary policy of the openness of the United Kingdom, both in trade and in financial transactions. Our view of this mechanism is strongly influenced by Rudiger Dornbusch's article in which he focuses on the interaction of an "efficient" foreign exchange market dominated by forward-looking speculators (possibly endowed with rational expectations), with disequilibrium in the domestic labor market in which the behavior of money wages is characterized by a significant degree of inertia. ${ }^{6}$ We attribute this nominal inertia as much to institutional features of the labor market such as the nature of labor contracts and the importance of relative wages or differentialsfeatures that we expect to remain to a large extent invariant under the kinds of policy regime changes the Thatcher government tried to implement-as to the presence of nonrational expectations in the labor market. ${ }^{7}$

Despite the increasing degree of unionization of the labor force in the United Kingdom after World War II, the process of collective bargaining in private industry is decentralized, staggered, and fragmented, which may account for some of the inertia. Thus, while in 1930 only 25 percent of the work force was in trade unions, by 1978 this had doubled to 54 percent, with particularly large growth during the previous decade and with

6. Rudiger Dornbusch, "Expectations and Exchange Rate Dynamics," Journal of Political Economy, vol. 84 (December 1976), pp. 1161-76.

7. It is, however, logically possible to attribute the marked difference in the response of the exchange market and the labor market to differences in the degree of credibility attached to the policies by the participants in these markets while maintaining a Walrasian, market-clearing, view of both sets of markets. This is another example of ad hoc specifications of information sets and ad hoc specifications of the wage-price mechanism generating observationally equivalent behavior of macroeconomic variables. 
half of all union members belonging to (postentry) closed shops. Moreover, single-employer agreements have replaced earlier industry-wide agreements concluded by employers' associations and trade unions. In today's environment, "the driving force behind pay increases in the private sector is coming from companies that possess considerable market power and below average sensitivity to changing conditions in the labour market." 8 In unions, too, there is decentralization with powerful local shop stewards but no authoritative central trade union council. It is worth noting that during the two decades since 1960 there have been very few periods when an incomes policy of some form was not in operation to check the inflationary potential of the wage-bargaining system. ${ }^{9}$

In the past decade, public sector pay has ceased to be a passive part of the national pay structure, and significant changes in the relative pay of public and private employees have occurred. ${ }^{10}$ Although the public sector contains roughly 30 percent of all employees and has ultimately one employer, the government, there is no consistent policy for determining public sector pay. Some groups are indexed to average earnings; some are offered "comparability" with analogous private sector employees; others are subject to cash limits or to the play of market forces. We argue that the initial failure to control the increase in public sector pay was one of the important factors that kept inflation high despite the restrictive monetary policy pursued by this administration.

In an open economy with a freely floating exchange rate, a high degree of international capital mobility, and inertia in the behavior of money wages, tight money will result in an immediate, large appreciation of the exchange rate. Since sluggish domestic costs do not exhibit the same flexibility, the jump in the nominal exchange rate also represents a jump in the real exchange rate-a sudden loss of competitiveness. Basically, restrictive monetary policy raises current and anticipated future real interest rates at home vis à vis those in the rest of the world. The real exchange rate jumps because it is a function of the entire current and anticipated future

8. William Brown and Peter Nolan, "The Context of the Next Incomes Policy," Policy Studies, vol. 1, pt. 3 (January 1981), p. 141.

9. S. G. B. Henry and P. A. Ormerod, "Incomes Policy and Wage Inflation: Empirical Evidence for the U.K., 1961-77," National Institute Economic Review, no. 85 (August 1978), p. 32.

10. Brown and Nolan, "The Context of the Next Incomes Policy," p. 142. 
path of real interest rate differentials. ${ }^{11}$ This short-run behavior of the real exchange rate has been referred to as real exchange rate "overshooting" because no long-run adjustment of the real exchange rate is required in response to monetary policy changes and other monetary disturbances. ${ }^{12}$

Real exchange rate overshooting results from current reductions in monetary growth, from credible announcements of future reductions in monetary growth, from current or anticipated future reductions in the level of the money stock, and from increases in indirect taxes. It is the asymmetry in the speed of response to "news" between the foreign exchange market (or financial markets in general) and the labor market that causes current and anticipated future developments in policy (and other exogenous shocks) to be reflected immediately in the exchange rate but only gradually in domestic wages.

As time passes, the overshooting gradually disappears, thus reducing both the output costs associated with the loss of competitiveness and the immediate anti-inflationary benefits from the sharp initial exchange rate appreciation.

In an economy like the United Kingdom's the exchange rate is viewed as a major link in the transmission mechanism of monetary and fiscal disturbances, operating along with the familiar channels in a closed economy such as nominal and real interest rates and other explicit or implicit rates of return, Tobin's $q$, wealth effects, cash-flow effects, and liquidity effects. This does not mean, however, that it is necessarily the external components of aggregate demand-exports and imports-that are primarily affected by tight money, at least not initially. The well-documented lags in the effect of competitiveness on exports (but not on new orders), which

11. With perfect capital mobility and risk neutrality, the relation is especially simple. Let $r$ be the domestic nominal interest rate, $r^{*}$ the world interest rate, $e$ the $\log$ of the spot price of foreign exchange, and $p$ and $p^{*}$ the logs of the domestic and foreign price level, respectively; a circumflex $(\boldsymbol{\Lambda})$ over a variable indicates its expected value. From $\hat{\hat{e}}=r-r^{*}$ one obtains $\hat{\hat{e}}+\hat{\hat{p}}^{*}-\hat{\hat{p}}=(r-\hat{\hat{p}})-\left(r^{*}-\hat{p}^{*}\right)$. This implies that $e(t)+p^{*}(t)-p(t)=\int_{t}^{\infty}\left[(\hat{r}(z)-\hat{\dot{p}}(z))-\left(\hat{r}^{*}(z)-\hat{\hat{p}}^{*}(z)\right)\right] d z$.

12. See Dornbusch, "Expectations and Exchange Rate Dynamics"; Willem H. Buiter and Marcus Miller, "Monetary Policy and International Competitiveness: The Problem of Adjustment," Oxford Economic Papers, Supplement: The Money Supply and the Exchange Rate, vol. 33 (July 1981), pp. 143-75; and Buiter and Miller, "Real Exchange Rate Overshooting and the Output Cost of Bringing Down Inflation," paper presented at the International Seminar on Macroeconomics, Paris, June 18-19, 1981 (rev. August 1981), forthcoming in European Economic Review. 
give rise to the $J$-curve, and the reluctance of exporters to reduce sales in response to a perceived transitory loss of competitiveness mean that the monetary transmission mechanism in an open economy may show up primarily in inventory adjustments.

In the next section we present a profile of the depression. This is followed by an analysis of monetary policy with a review of the theory and practice of monetary control in the United Kingdom, a closer look at the government's medium-term financial strategy, and an assessment of the degree to which monetary policy has been restrictive. Fiscal policy is then discussed as is the influence of exogenous shocks and the role of North Sea oil. The conclusion offers a tentative balance sheet for the Thatcher experiment.

\section{A Profile of the Current Depression}

In 1980 the economy of the United Kingdom entered the deepest slump since the Second World War. So pronounced has been the contraction of economic activity that current developments bear comparison with the onset of the Great Depression after 1925, as illustrated in figure 1.

The present downturn is much deeper than that being experienced by other industrial countries, as can be seen by comparing the GDP for the United Kingdom and the Organization for Economic Cooperation and Development (OECD). While the annual growth rate of real GDP for the OECD as a whole slowed to 1.2 percent in 1980 , that is, 2.3 percentage points less than the average growth experienced over the preceding decade, real GDP fell by 1.7 percent in the United Kingdom that year, a performance that is almost 4 percentage points below its average over the preceding decade. A similar relative performance appears likely in $1981 .{ }^{13}$

PRODUCTION, AGgREgATE DEMAND, AND

DEMAND COMPONENTS

As shown in table 1, real GDP began its slide at the end of 1979. Preliminary indications are that as of July-August 1981 the decline of real

13. National Institute Economic Review, no. 97 (August 1981), p. 35, in which GDP for the United Kingdom is measured on an expenditure basis. 
Figure 1. Comparison between 1925-35 and 1975-81, Selected Indicators ${ }^{\mathrm{a}}$
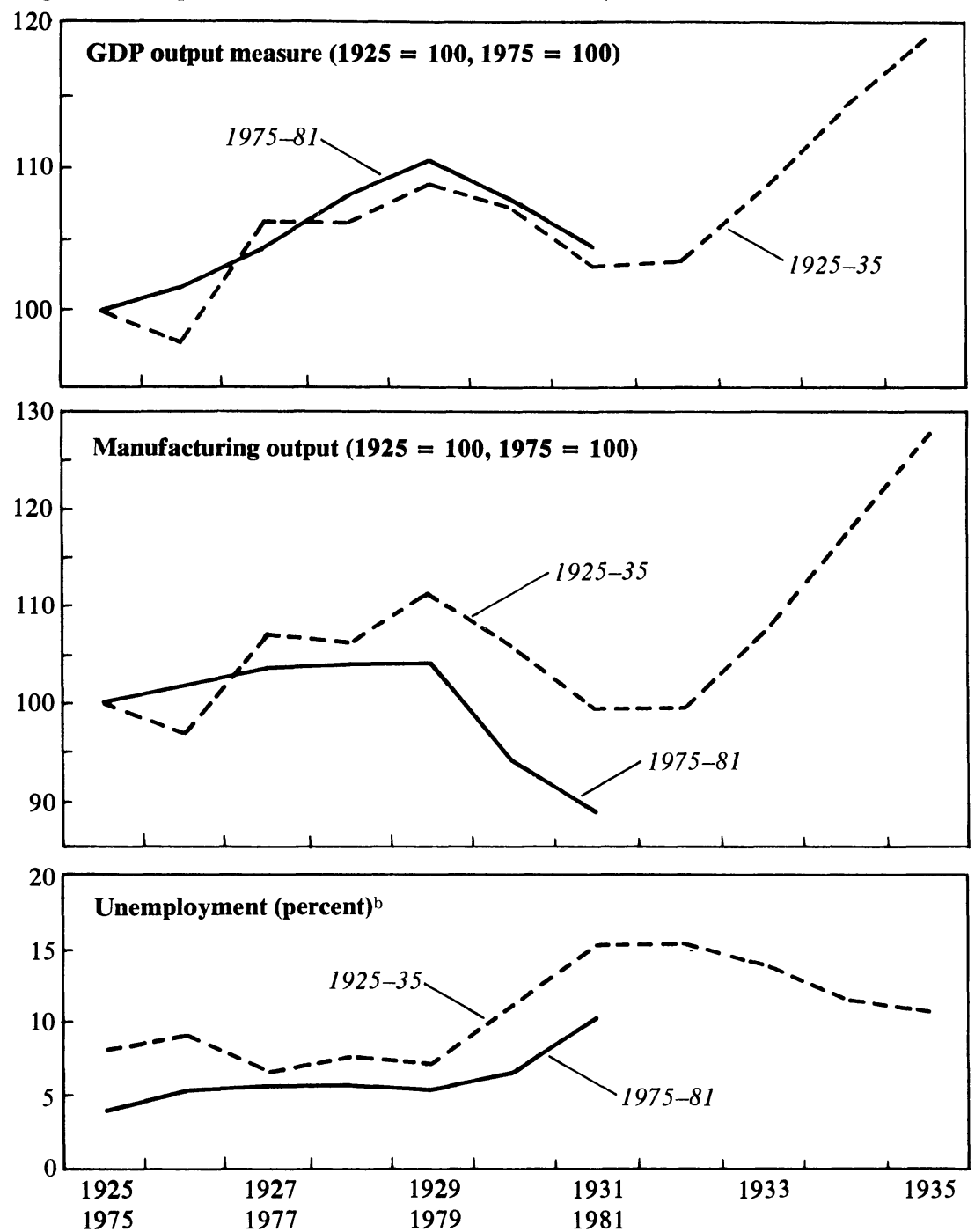

Sources: Based on the figure presented in the National Institute Economic Review, no. 95 (February 1981), p. 7. Data for 1925-35 are from C. H. Feinstein, National Income, Expenditure and Output of the United Kingdom, 1855-1965, Studies in the National Income and Expenditure of the United Kingdom 6 (Cambridge University Press, 1972), tables 6, 51, 57, pp. T19, T112, T126; data for 1975-81 are from United Kingdom, Central Statistical Office, Economic Trends, no. 334 (August 1981), pp. 6, 28, 36.

a. The estimate of GDP (on the output measure) for 1981 is the average of the first two quarters (value of 104.0); the estimate of manufacturing output for 1981 is the average of the first three quarters (value of 89.1); the estimate of unemployment for 1981 is the average of the first ten months (value of 10.4). These data are from Economic Trends, no. 337 (November 1981), pp. 6, 26, 36.

b. In the 1925-35 period the unemployed of the civilian working population, including work temporarily stopped; in the 1975-81 period the percent of employees, excluding school leavers under age seventeen. 


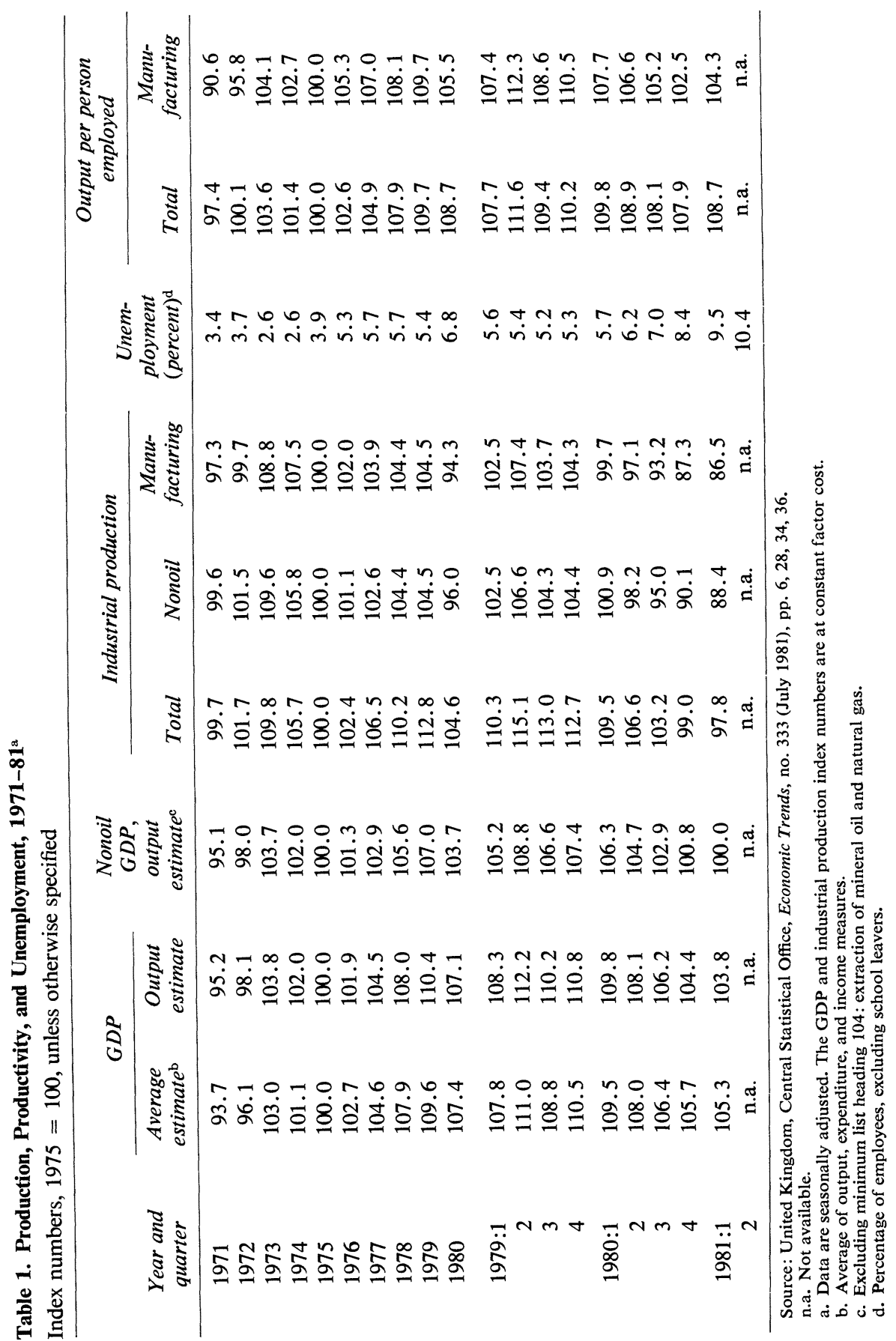


GDP has stopped. Between 1979:4 and 1981:1 real GDP fell 4.7 percent measured by the average estimate. ${ }^{14}$ The decline in nonoil GDP was larger over that period, amounting to 6.9 percent. As usual, industrial production was affected disproportionately, with total industrial production and nonoil industrial production falling by 13.2 percent and 15.3 percent, respectively, between 1979:4 and 1981:1. Manufacturing production fell by 17.1 percent during the same period.

The behavior of the major components of aggregate demand is given in table 2, which shows that the $£ 2,786$ million decline in real GDP between 1979 and 1980 is arithmetically more than that accounted for by a turnaround in inventory accumulation of $£ 3,499$ million. ${ }^{15}$ Inventory liquidation continued through 1981:1. As a result of the massive destocking, the inventory-production and inventory-sales ratios have returned to levels close to their historical trends.

Public consumption spending grew moderately at about 2 percent from 1979 to 1980 , and for 1981 it also appears as though the government's plans to reduce real public consumption will not be achieved. ${ }^{16}$ Consumer expenditure also proved remarkably resilient. This can be related to a significant rise in real disposable personal income, which more than offset a high personal saving ratio.

Fixed capital formation (private plus public) grew through 1979 but turned down from the beginning of 1980 . The growth of public consumption stands in sharp contrast to the dramatic decline in capital formation in the public sector, primarily by general government but also by the public corporations. There appears to have been for many years a firm and successful bipartisan commitment to reduce investment in social overhead capital. General government capital formation was 19 percent lower in 1981:1 than it had been a year earlier. ${ }^{17}$ The corresponding decline in investment by public corporations was 5.4 percent.

Real exports, after being surprisingly buoyant through 1980:1, turned downward after an unprecedented loss of competitiveness. Import volumes had risen sharply between 1978 and 1979, producing a $£ 2.9$ billion decline in the real trade balance. On a quarterly basis, imports peaked

14. Average of output, expenditure, and income measures.

15. By the expenditure measure.

16. This spending is public expenditure on goods and services other than public sector capital formation and inventory accumulation.

17. United Kingdom, Central Statistical Office, Economic Trends, no. 333 (July $1981)$, p. 16. 


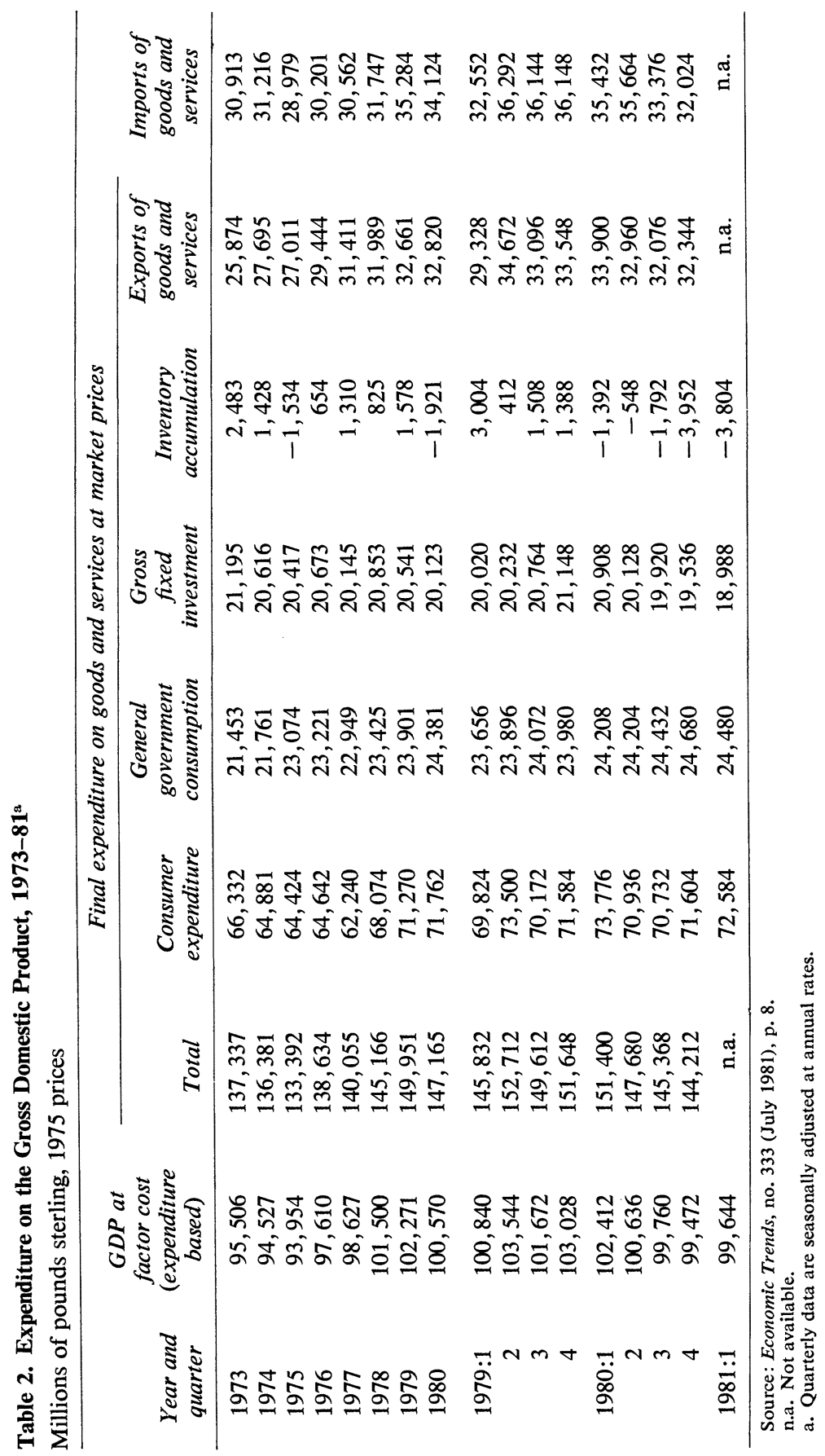


by mid-1979 and declined sharply after 1980:2, reflecting the influence of the depression in general and of inventory liquidation in particular.

\section{UNEMPLOYMENT AND LABOR PRODUCTIVITY}

As can be seen from the seventh column of table 1, unemployment has been on a rising trend since the first oil shock of 1973-74; but the increase has been dramatic during the slump, with the unemployment rate reaching 10.4 percent in $1981: 2$, double what it was in 1979:3.

Real GDP (average estimate) rose by 1 percent a year between the two peak years of 1973 and 1979. However, this growth in production understates the conventional estimates of the potential growth rate of the economy-unemployment was twice as high in 1979 as it was in 1973. (Below we use an estimate of $13 / 4$ percent as the annual growth of potential GDP from 1979 on.) As output has fallen from 1979 to 1980, output per person also declined but only by 0.9 percent. ${ }^{18}$ Until the beginning of 1981 the ratio of the shortfall of GDP below trend and the unemployment rate was broadly in accordance with what is known as "Paish's ratio," the equivalent of Okun's law for the United Kingdom. On the basis of the experience of the 1970s this predicts that the increase in the unemployment rate will be about half of the percentage increase in the gap between potential and actual GDP. ${ }^{19}$ Since the beginning of 1981, however, the rise in the unemployment rate has been much greater than would have been predicted on the basis of past relations.

Both labor productivity and unemployment are higher in 1981 than the United Kingdom equivalent of Okun's law would predict. This fact could be due to either or both of two developments. First, there may have been a step increase in the cyclically adjusted level of productivity in the economy of the United Kingdom as a result of current policy; second, the sort of labor hoarding that lessens measured productivity in a recession may have ceased as firms gave up hope of a quick recovery.

18. Output per person employed in manufacturing fell by 4 percent in 1980 , much more than that for the economy as a whole. Part of the difference may come from the increase of part-time hours worked in manufacturing and the lack of overtime; hours worked per production worker fell by almost 3 percent between 1979 and 1980 .

19. Frank W. Paish, Studies in an Inflationary Economy: The United Kingdom, 1948-1961 (London: Macmillan, 1962). 
The government is inclined to stress the first of these two explanations, citing an increase in labor productivity in 1981:1, while output was still falling, as preliminary evidence of a new dawn of greater efficiency and productivity. However, its own cautious forecasts for the future path of GDP would certainly give support to the second view: why should firms that believed the Chancellor's assumption that GDP would only rise $1 / 2$ percent a year from 1980 to 1983 hoard labor? ${ }^{20}$

\section{WAGES AND PRICES}

Although reducing the rate of inflation was the overriding priority of the incoming Thatcher government, some of its own policies initially worsened the inflation problem. The incomes policy pursued by the Labour government broke down in the course of 1978 and the pace of wage settlements increased sharply, as can be seen from the second column of table 3: the rate of increase of basic (manual) wage rates over the year to $1978: 4$ was 18.1 percent, compared with 5.4 percent the previous year. In an attempt to obtain industrial peace during the "winter of discontent" that followed the breakdown of its incomes policy, the Labour government committed itself to large increases in public sector wages, some of them to be phased in during 1979. During the election campaign in early 1979 the Conservatives promised that they, too, would honor these commitments.

The result was disastrous for the anti-inflationary policy and for the attempts to control public spending and the PSBR: in the 1979-80 financial year public sector earnings rose 25 percent and, for employees of the central government, wages rose over 30 percent. ${ }^{21}$ Such settlements were higher than those in the private sector, but the index of earnings for the economy as a whole still rose by 21.4 percent in the year to 1980:2.

In the second half of 1980 the government announced that the Pay Comparability Commission, which had been setting the pace for public sector settlements, would be abolished; it suspended the pay agreement for 1981 affecting 550,000 white-collar civil servants, a move adopted by the previous government during the two phases of its incomes policy

20. United Kingdom, Financial Statement and Budget Report, 1981-82 (HMSO, $1981)$, p. 17.

21. See National Institute Economic Review, no. 95 (February 1981), p. 11. Financial years begin in April of the year indicated. 
Table 3. Wage and Price Inflation, 1973-81

Percent change per year ${ }^{\mathrm{a}}$

\begin{tabular}{rrrrrrrrr}
\hline & $\begin{array}{c}\text { Average } \\
\text { earnings, } \\
\text { Year and } \\
\text { wharter }\end{array}$ & $\begin{array}{c}\text { Basic } \\
\text { weekly } \\
\text { economy }\end{array}$ & $\begin{array}{r}\text { wage } \\
\text { rates }\end{array}$ & $\begin{array}{c}\text { Retail } \\
\text { price } \\
\text { index }\end{array}$ & $\begin{array}{c}\text { Tax and } \\
\text { price } \\
\text { index }\end{array}$ & $\begin{array}{c}\text { GDP } \\
\text { deflator }\end{array}$ & $\begin{array}{c}\text { Real } \\
\text { consump- } \\
\text { tion } \\
\text { wage }^{\text {c }}\end{array}$ & $\begin{array}{c}\text { Real } \\
\text { product } \\
\text { waged }^{\text {dind }}\end{array}$ \\
\hline $1973: 4$ & 12.5 & 11.8 & 10.3 & n.a. & 8.3 & 1.5 & 3.5 \\
$1974: 4$ & 25.4 & 26.6 & 18.2 & n.a. & 22.1 & 8.4 & 4.5 \\
$1975: 4$ & 21.6 & 26.1 & 25.3 & n.a. & 24.4 & 0.8 & 1.7 \\
$1976: 4$ & 12.3 & 13.9 & 15.0 & n.a. & 11.9 & -1.1 & 2.0 \\
$1977: 4$ & 8.9 & 5.4 & 13.0 & n.a. & 10.8 & -7.6 & -5.4 \\
$1978: 4$ & 13.8 & 18.1 & 8.1 & n.a. & 10.8 & 10.0 & 7.3 \\
$1979: 4$ & 18.5 & 15.5 & 17.3 & 14.9 & 16.0 & -1.8 & -0.5 \\
$1980: 4$ & 19.5 & 16.3 & 15.3 & 16.4 & 17.5 & 1.0 & -1.2 \\
$1979: 1$ & 13.9 & 19.8 & 9.6 & 6.6 & 9.7 & 10.2 & 10.1 \\
2 & 13.4 & 12.1 & 10.6 & 13.8 & 12.1 & 1.5 & 0.0 \\
3 & 15.7 & 12.8 & 16.0 & 14.1 & 14.1 & -3.2 & -1.3 \\
4 & 18.5 & 15.5 & 17.3 & 16.9 & 16.0 & -1.8 & -0.5 \\
$1980: 1$ & 19.7 & 17.6 & 19.1 & 17.6 & 17.6 & -1.5 & 0.0 \\
2 & 21.4 & 19.2 & 21.5 & 17.4 & 19.2 & -2.3 & 0.0 \\
3 & 22.2 & 19.2 & 16.4 & 17.3 & 18.8 & 2.8 & 0.4 \\
4 & 19.5 & 16.3 & 15.3 & 16.4 & 17.5 & 1.0 & -1.2 \\
$1981: 1$ & 16.5 & 12.5 & 12.7 & 13.5 & 14.8 & -0.2 & -2.3 \\
2 & 13.0 & 9.9 & 11.7 & 15.3 & n.a. & -1.8 & n.a. \\
\hline
\end{tabular}

Source: Economic Trends, no. 334 (August 1981), pp. 5, 6, 40, 42, and similar tables in preceding issues. n.a. Not available.

a. Percent changes are from same quarter one year earlier.

b. Manual workers.

c. Change in the basic weekly wage rate minus change in the retail price index.

d. Change in the basic weekly wage rate minus change in the GDP deflator.

e. Provisional data.

of 1975-77. ${ }^{22}$ It also announced that cash limits for local authorities in 1981-82 would only include provision for a 6 percent increase in the wage bill.

It was the rate of increase of prices that the new administration made the target of its policy, and the index commonly utilized for measuring price inflation in settling wage bargains is the increase in the retail price index over the past twelve months shown in the third column of table 3. The rate of inflation on this measure increased sharply in the third quarter of 1979 as a direct consequence of the 7 percent increase in the

22. After a protracted dispute, the civil servants settled for $71 / 2$ percent in mid1981. 
value added tax in the June budget of that year, which was estimated to have added about 4 points to the average level of prices. This increase stayed in the "inflation rate," as measured by the year-over-year change in the retail price index, for a whole year. Given the convention of effectively indexing annual pay claims for past inflation and the tendency to use recent inflation as a guide to future inflation, there can be little doubt that the increase of the value added tax in June 1979 helped to keep the pace of settlements at a high level in the subsequent pay round. ${ }^{23}$

The government actually cut direct taxation by enough to maintain the real value of the after-tax wage and hoped that wage settlements would not attempt to make up for the increase in value added taxes. To help make this point, the government in August 1979 introduced the tax and price index, which shows how much gross earnings would need to be increased to compensate for changes in market prices and direct taxes. This measure showed no marked jump after the June 1979 budget, but it was launched too late to moderate the 1979-80 wage round. Furthermore, in the fall of the following year the tax and price index was rising faster than the retail price index and has continued to do so.

The retail price index was also being pushed up by the increase in world oil prices. As with other developments that boosted consumer prices, energy price increases accelerated the whole wage-price spiral. In equilibrium, maintaining production and high employment after an energy price increase would require a reduction in unit labor and capital costs. However, real wage targets in bargaining, together with the refusal of the government to cut taxes in line with its expected North Sea revenues, have prevented such a reduction of real wage costs.

After the first oil shock in 1973-74, the incomes policy of the Conservative government was challenged by the coal miners, and when an election was called, the government was voted out of office. There followed a veritable wage explosion that raised real wages by 8.4 percent in 1974 and pushed the annual inflation rate, as measured by the GDP deflator, well above 20 percent. The Labour government's incomes policy, which began in the fall of 1976, slowed wages more than prices, and real wages lost the gain achieved in the previous two years. With the breakdown of incomes policy, however, real wages rose by 10 percent in 1978 and have changed little through mid-1981.

23. De facto indexing occurred despite the absence of formal cost-of-living allowances. 
THE CURRENT ACCOUNT, COMPETITIVENESS, AND THE EXCHANGE RATE

One of the most striking aspects of the current depression is the collapse of the international competitiveness of the United Kingdom, as shown in table 4. The loss of competitiveness during 1979 and 1980 is about 50 percent when measured by the International Monetary Fund indexes of relative unit labor costs, and this is mirrored, though more modestly, by other indexes..$^{24}$ North Sea oil, together with the rise in world oil prices, may have contributed to the appreciation of sterling and the loss of competitiveness. But the restrictive monetary policy of the government was probably even more important. Both of these effects are discussed below.

The 21.6 percent increase in the effective exchange rate between 1979:1 and 1980:4 and the 46.2 percent loss of competitiveness, as measured by relative normalized unit labor costs, together imply that, far from compensating for international inflation differentials over this period, movements in the effective exchange rate compounded the divergence of domestic and foreign costs. ${ }^{25}$

The large deterioration in cost competitiveness, as measured by relative normal unit labor costs, was evidently absorbed to a considerable extent by exporters squeezing their profit margins so as to limit their loss of price competitiveness in international markets. The unit value index for manufactured exports, measured in sterling, rose only 16.8 percent from 1979:1 to 1980:4, while the GDP deflator rose by 32.1 percent and wage and salary costs per unit of output in manufacturing rose by 36.6 percent. ${ }^{26}$ Exports were maintained relatively well, while inventories and production were cut back.

Thus, although the loss of competitiveness was one of the major proximate causes of the depression, it did not operate primarily by lowering

24. Between 1979:1 and 1980:4 relative export prices increased by 21.4 percent; relative wholesale prices rose by 30.0 percent; the index of import price competitiveness worsened by 11.1 percent; and the relative profitability of exports deteriorated by 5.9 percent. See Economic Trends, no. 333 (July 1981), p. 46.

25. By October 1981, when the pound had fallen to 1.82 U.S. dollars, its effective rate had declined by some 14 percent from its peak in 1981:1. Cost inflation in the United Kingdom since then has probably been near the average elsewhere, so this depreciation will constitute a substantial recovery of competitiveness since 1981:1.

26. Economic Trends, no. 333 (July 1981), pp. 6, 40. 
Table 4. Trade Competitiveness of the United Kingdom and Sterling Exchange Rates, 1975-81

\begin{tabular}{cccc}
\hline Tnternational & $\begin{array}{c}\text { Intary Fund } \\
\text { Monetary } \\
\text { index of relative } \\
\text { unit labor costs, } \\
\text { normalized } \\
\text { quarter }\end{array}$ & $\begin{array}{c}\text { Sterling-dollar } \\
\text { (1975=100) }\end{array}$ & $\begin{array}{c}\text { Sterling effective } \\
\text { exchange rate } \\
(1975=100)^{\mathrm{a}}\end{array}$ \\
\hline 1975 & 100.0 & 2.220 & 100.0 \\
1976 & 93.6 & 1.805 & 85.7 \\
1977 & 89.9 & 1.746 & 81.2 \\
1978 & 97.9 & 1.920 & 81.5 \\
1979 & 113.0 & 2.122 & 87.3 \\
1980 & 138.9 & 2.328 & 96.1 \\
$1979: 1$ & 102.4 & 2.016 & 82.4 \\
2 & 112.0 & 2.081 & 87.0 \\
3 & 118.7 & 2.234 & 91.3 \\
4 & 119.0 & 2.157 & 88.5 \\
$1980: 1$ & 126.4 & 2.254 & 93.0 \\
2 & 136.0 & 2.286 & 94.5 \\
3 & 143.4 & 2.382 & 96.7 \\
4 & 149.7 & 2.387 & 100.2 \\
$1981: 1$ & 156.2 & 2.309 & 101.4 \\
2 & n.a. & 2.077 & 97.8 \\
\hline
\end{tabular}

Source: Economic Trends, no. 334 (August 1981), pp. 46, 50.

a. Index combining the exchange rates between sterling and seventeen other major currencies with weights derived from the International Monetary Fund's multilateral exchange rate model.

export demand during the 1978-80 period. As table 2 shows, real exports of goods and services rose in 1979 and rose slightly further in 1980, although they were declining after the first quarter of that year. Real imports did surge in 1979, although most of the increase preceded the steep appreciation of sterling. Imports declined in 1980 , but by then it is difficult to allow for the effects of the depression in the United Kingdom so as to identify the effects of competitiveness.

The current account moved sharply from deficit into surplus after 1980:2. There was even the unusual phenomenon of a surplus on the visible trade balance. ${ }^{27}$ It would be superficial to attribute this simply to

27. The Civil Service dispute has interrupted the publication of trade figures since early in 1981. Data available for September 1981 show a dramatic rise in import volume, a rise in export volume, and a virtual disappearance of the surplus on visible trade. Too much significance should not be attached to one month's trade figures, however. 
the rapid growth of domestic oil production and the movement of the United Kingdom into oil self-sufficiency. The current account is the balance between total output and total absorption and is not related in any simple and direct way to changes in the production of any particular traded commodity. The combination of the growing volume of oil production and the low "propensity to absorb" of the British government, the major single beneficiary from oil revenues, does create a tendency toward current account surplus. However, most of the improvement in this period can be attributed to the unprecedented severity of a depression characterized by massive inventory liquidation.

\section{Monetary Control in the United Kingdom}

A central feature of the Thatcher government's economic policy is control of the growth rate of money. For this purpose, the chosen intermediate monetary target is sterling M3, a fairly broad aggregate consisting of notes and coins in public circulation, together with all sterling bank deposits, including certificates of deposit, held by residents of the United Kingdom in both the public and private sectors. The government has been frustrated in its attempt to control sterling M3 despite the fact that monetary policy, as we argue below, has been very restrictive. In order to examine why this is so, we explain the nature of the sterling M3 aggregate in the British financial system and the way it responds to monetary policy and economic developments.

About 60 percent of sterling M3 consists of interest-bearing deposits, the rates on which are determined by banks in competition with other financial institutions. For such a broad definition of money it is not the level of interest rates in general that affects the demand for money but rather the differential between rates available on nonmoney assets and those paid by banks. On the assumption that the rates banks charge their loan customers are close to those prevailing elsewhere and that bank margins are kept narrow by competition, one would not expect this interest differential to be much affected by the level of interest rates. Hence for a competitive banking system the demand for broad money will appear to be relatively inelastic with respect to the general level of interest rates. The monetary authorities, who had in a series of monetary reforms in 1971 
encouraged the banking system to compete aggressively for deposits, found it necessary to check such competition two years later by introducing supplementary special deposits. Under this scheme, banks were required to hold noninterest-bearing deposits at the Bank of England if the growth in the interest-bearing element of their deposits exceeded defined limits. The proportion of the marginal excess deposits that had to be lodged at the Bank of England rose to a maximum of 50 percent as a bank moved further into the penalty zone. This scheme, popularly referred to as the "corset," was in force when the Conservative administration took office in June 1979. In its second budget, however, the Chancellor decreed that it should be scrapped in June 1980 because the authorities believed the corset scheme caused disintermediation, the "cosmetic" control of the chosen monetary target being achieved without effective control over underlying monetary conditions.

The argument that financial institutions in competition with banks would have a powerful incentive to create substitutes for the deposits subject to such direct controls is reminiscent of similar objections to regulation $Q$ in the United States. In the British case it came to be described by "Goodhart's law," after Charles Goodhart of the Bank of England, which asserts that when the authorities attempt to control any monetary total, the activities of the financial system in creating substitutes will so affect its demand and supply that its behavior will cease henceforth to reflect accurately the course of banking business.

The Conservative administration was acutely aware of this criticisma Lucas critique of methods of monetary control-since the effect of removing exchange controls in 1979 had been to open up a loophole for banks to evade the corset by sending business offshore (just as U.S. banks could evade regulation $\mathrm{Q}$ by routing business through the Eurodollar market). The abolition of the corset resulted in a dramatic increase in sterling M3-both absolute and relative to the other aggregates-with reintermediation adding about 4 percent to sterling M3. This was more than the Bank of England had expected, and such a large increase in the indicator chosen to show the underlying rate of monetary growth was embarrassing to the government.

In 1980 the Treasury and the Bank of England published a consultation paper, Monetary Control, which concluded that the principal methods to be used to control the money supply in the absence of the corset 
scheme would be the level of interest rates and the public sector borrowing requirement. ${ }^{28}$ Control over interest rates would be achieved by open market operations, especially in Treasury bills and-until mid-1981-by varying the minimum lending rate, which is the minimum rate at which the Bank of England lends cash to the market. Control over the PSBR would be achieved by varying taxes and expenditures. Broadly speaking, the proposed methods of control were seen as operating primarily on the demand for credit from the banking system, both by the authorities and by the private sector, rather than on the demand for bank liabilities (deposits). Thus to understand how the methods of control were expected to work, we must consider the asset side of the banks' balance sheet in addition to the deposit side.

Sterling M3 can be written as sterling M3 $\equiv$ notes and coin + sterling deposits of the United Kingdom residents. The balance sheet of banks in the United Kingdom can be shown as

\section{Liabilities}

Sterling deposits of residents of the United Kingdom

Sterling deposits of overseas residents

Foreign currency deposits

Nondeposit liabilities

\section{Assets}

Sterling lending to the United Kingdom private sector

Sterling lending to the public sector

Sterling lending to overseas residents

Foreign currency lending

This implies

$\Delta$ sterling $\mathrm{M} 3 \equiv \Delta$ notes and coin $+\Delta$ sterling lending to the United Kingdom public and private sector

$+\Delta$ sterling lending to overseas residents

$-\Delta$ overseas residents' sterling deposits $-\Delta$ foreign currency deposits net of foreign currency lending

$-\Delta$ nondeposit liabilities.

Combining these with the financing identity for the government sec-

28. Monetary Control, a consultation paper by the Treasury and the Bank of England, presented to Parliament by the Chancellor of the Exchequer, Cmnd. 7858 (HMSO, 1980). 
tor $^{29}$ (for whom government borrowing from the banks is a residual source of finance covering borrowing needs not met overseas or by the nonbank private sector), we obtain an equation accounting for the change in sterling M3 from the asset side as follows:

$\Delta$ sterling M3 $\equiv$ PSBR - sales of public sector debt to United Kingdom private nonbank sector

$+\Delta$ bank lending (to United Kingdom private sector and overseas residents)

+ net external flows ${ }^{30}$

$-\Delta$ banks' nondeposit liabilities.

More compactly, combining the first three terms on the right-hand side,

$\Delta$ sterling $\mathrm{M} 3 \equiv$ domestic credit expansion

+ net external flows

$-\Delta$ banks' nondeposit liabilities.

We agree with Artis and Lewis in their observation: "This simple framework ... now forms the basis of monetary control, and of public discussion of it, in Britain. Because DCE [Domestic Credit Expansion] relates to the asset, or lending side, of the banks' balance sheet, the Bank [of England] is able to satisfy those who argue that bank credit and not the money supply should be the focus of policy, since the target subsumes it. Moreover, because the PSBR, gilt sales and external flows can be identified with fiscal policy, debt management, and exchange rate policies respectively, the framework shows the interrelationship of the various arms of economic policy." ${ }^{31}$

29. The financing of the PSBR is expressed as

PSBR $=\Delta$ notes and coin + sales of public sector debt to the United Kingdom private nonbank sector

+ external finance of the public sector

$+\Delta$ sterling lending to public sector by the banking system.

30. Net external flows $\equiv-$ external finance of public sector $-\Delta$ overseas residents' sterling deposits $-\Delta$ foreign currency deposits net of foreign currency lending.

31. M. J. Artis and M. K. Lewis, Monetary Control in the United Kingdom (London: Philip Allan, 1981), pp. 68, 70. 
Table 5. Changes in Sterling M3 and Its Components, Financial Years 1978-79 through 1980-81 ${ }^{\mathrm{a}}$

Millions of pounds sterling

\begin{tabular}{|c|c|c|c|c|c|c|c|}
\hline Period & $\begin{array}{c}\text { Public } \\
\text { sector } \\
\text { borrowing } \\
\text { require- } \\
\text { ment } \\
(1)\end{array}$ & $\begin{array}{l}\text { Public } \\
\text { sector } \\
\text { debt sales } \\
\text { to private } \\
\text { nonbank } \\
\text { sector } \\
(2)\end{array}$ & $\begin{array}{c}\text { Increase } \\
\text { in bank } \\
\text { lending } \\
\text { (3) }\end{array}$ & $\begin{array}{c}\text { Domestic } \\
\text { credit } \\
\text { expansion }^{\mathrm{c}} \\
(4)\end{array}$ & $\begin{array}{l}\text { Net } \\
\text { external } \\
\text { flows }^{\mathrm{d}} \\
(5)\end{array}$ & $\begin{array}{c}\text { Increase } \\
\text { in non- } \\
\text { deposit } \\
\text { liabilities } \\
\quad(6)\end{array}$ & $\begin{array}{c}\text { Increase } \\
\text { in } \\
\text { sterling } \\
M 3^{\mathrm{e}} \\
(7)\end{array}$ \\
\hline 1978-79 & 9,199 & 8,534 & 6,778 & 7,443 & -951 & $-1,043$ & 5,449 \\
\hline 1979-80 & 10,474 & 9,138 & 9,874 & 11,210 & $-2,743$ & $-1,347$ & 7,120 \\
\hline 1980-81 & 13,145 & 10,840 & 12,947 & 15,252 & $-3,153$ & $-1,482$ & 10,617 \\
\hline
\end{tabular}

Source: Economic Trends, no. 334 (August 1981), p. 54.

a. Data are seasonally adjusted. Financial years begin in April of the first year shown. Sterling M3 includes notes and coins in circulation plus all sterling deposits, including certificates of deposit, held by residents of the United Kingdom in both the public and private sectors.

b. Sterling lending to the private sector of the United Kingdom and to overseas residents.

c. Column 4 is column 1 minus column 2 plus column 3 .

d. See note 30 .

e. Column 7 is column 4 plus columns 5 and 6 .

In table 5 the behavior of the components of sterling M3 is shown for the 1978-81 period. How the two instruments of monetary control are expected to operate is outlined with references to that table. Leaving aside the external factors (to be neutralized by the floating exchange rate) and nondeposit liabilities (bank equity finance), a rise in short-term interest rates is expected to increase sales of public sector debt to the nonbank private sector (column 2) or to check demand for bank lending in sterling (column 3). If interest rates fail to check the growth of sterling M3 in this way, it is the government's own borrowing requirement that must be reduced (column 1). As Artis and Lewis observe, however, the results of this bank-asset approach to controlling the money supply "have so far been disappointing, to put it mildly. Apart from spurts in gilt-edged sales, the response of $£ \mathrm{M} 3$ to interest rate variations appears slow and uncertain. By directing attention to each of the components and away from the total money supply, the markets tend to react adversely when any one component is misbehaving, not appreciating that it may be counteracted by one of the other items. In particular, overruns in PSBR targets have encouraged the authorities to subsume fiscal policy almost entirely to the dictates of monetary control, despite difficulties in containing the deficit in the face of rising unemployment." ${ }^{32}$

32. Ibid., p. 84. 
In abandoning the corset scheme that gave them some control over the interest differentials that alter the attractiveness of the interest-bearing component of bank deposits, the authorities appear to have relied largely on the notion that high interest rates will control the volume of bank credit by restricting the demand for credit from the banks, both by the public and the private sectors. But if one considers the "residual" demand for bank credit by the public sector, the very factor that makes the demand for sterling M3 insensitive to the level of interest rates will also make the demand for public sector debt by the nonbank private sector interest inelastic: a rise in interest rates will not make public sector debt more attractive to the nonbank private sector if rates on deposits also rise. Similarly, there is no reason to expect that a rise in the general level of interest rates will divert private borrowers to other sources of finance and away from the banking system whose rates are by assumption moving in line with rates in general.

In short, varying the level of interest rates is likely to fail to depress significantly the rates paid on interest-bearing deposits relative to those available on near-bank deposits, and to raise the cost of bank credit relative to costs of borrowing elsewhere. ${ }^{33}$

Although the two chosen weapons of monetary control do not bear differentially on the banks, the effort to control the money supply through interest rates will surely have an effect on the flow of investment (including inventory investment), on the exchange rate, and on the level of income and prices, and will indirectly affect the demand for money and credit. ${ }^{34}$ Moreover, discretionary changes in the PSBR will, by changing the stance of fiscal policy, surely have effects on the economy and so on the demand for money and credit. Rather than the instruments of policy controlling the money supply so as to affect prices and output, these instruments have to affect the economy in order to control the money supply.

Against the background of this analysis, we now turn to a discussion of how policy actually was formulated and how actual developments compared with the government's plans.

33. For further discussion see Marcus Miller, "Monetary Control in the U.K.," Cambridge Journal of Economics, vol. 5 (March 1981), pp. 71-79.

34 . Indeed, in the current recession, when company profits are badly squeezed but personal real disposable incomes are not, there appears to be a rise in the demand for credit by companies and for deposits by persons as they recycle the transitory shift in their incomes. 


\section{The Medium-Term Financial Strategy}

The government's medium-term financial strategy was supposed to integrate fiscal and monetary policy in a particular way. According to the MTFS launched in the 1980 budget, inflation was to be controlled by restraining the growth of the broadly defined money supply, sterling M3, within an announced target range; but this monetary objective was to be achieved "without excessive reliance on interest rates" by adjusting the PSBR. ${ }^{35}$ Thus, although cuts in the level of government spending and in direct taxation were planned, fiscal policy, as measured by the PSBR, was to be geared to the attainment of monetary objectives and not to stabilizing the level of output.

The government was prepared to announce four years in advance the path for the PSBR that it felt was consistent with its plans for monetary growth. The planned coordination of fiscal and monetary policy are shown in figure 2 , in which the arrow shows the strategy for reducing both monetary growth and the government's borrowing requirement as a percentage of output.

The upper and lower edges of the box at the left side of the figure show the upper and lower limits set for monetary growth. Thus the figure shows a range for the targeted monetary growth but only a point estimate for the ratio of the deficit to GDP. Because the latter was a "consistent projection" and not a target, it would be more accurate to show a range for this, too, but none has been published. The government has in fact assigned great weight to the published PSBR/GDP ratios in its conduct of fiscal policy, so it is not, we believe, too misleading to portray the monetary and fiscal plans in this way.

As indicated in the figure, the planned link between monetary growth and the government's deficit was much tighter than any link that may have prevailed in the past. The actual outcome for 1980-81 greatly exceeded both objectives, though this by no means implies that monetary and fiscal policy were excessively expansionary, for reasons that are spelled out below.

The fiscal content of the MTFS lies not only in its plans for the PSBR,

35. Memoranda on Monetary Policy, House of Commons Treasury and Civil Service Committee, sess. 1979-80, vol. 1 (HMSO, 1980), p. 19. 
Figure 2. Monetary Growth and the Ratio of the Public Sector Borrowing Requirement to Gross Domestic Product, Initial Plans and Past Performance,

Financial Years 1963-64 through 1983-84a

Growth of sterling M3 (percent)

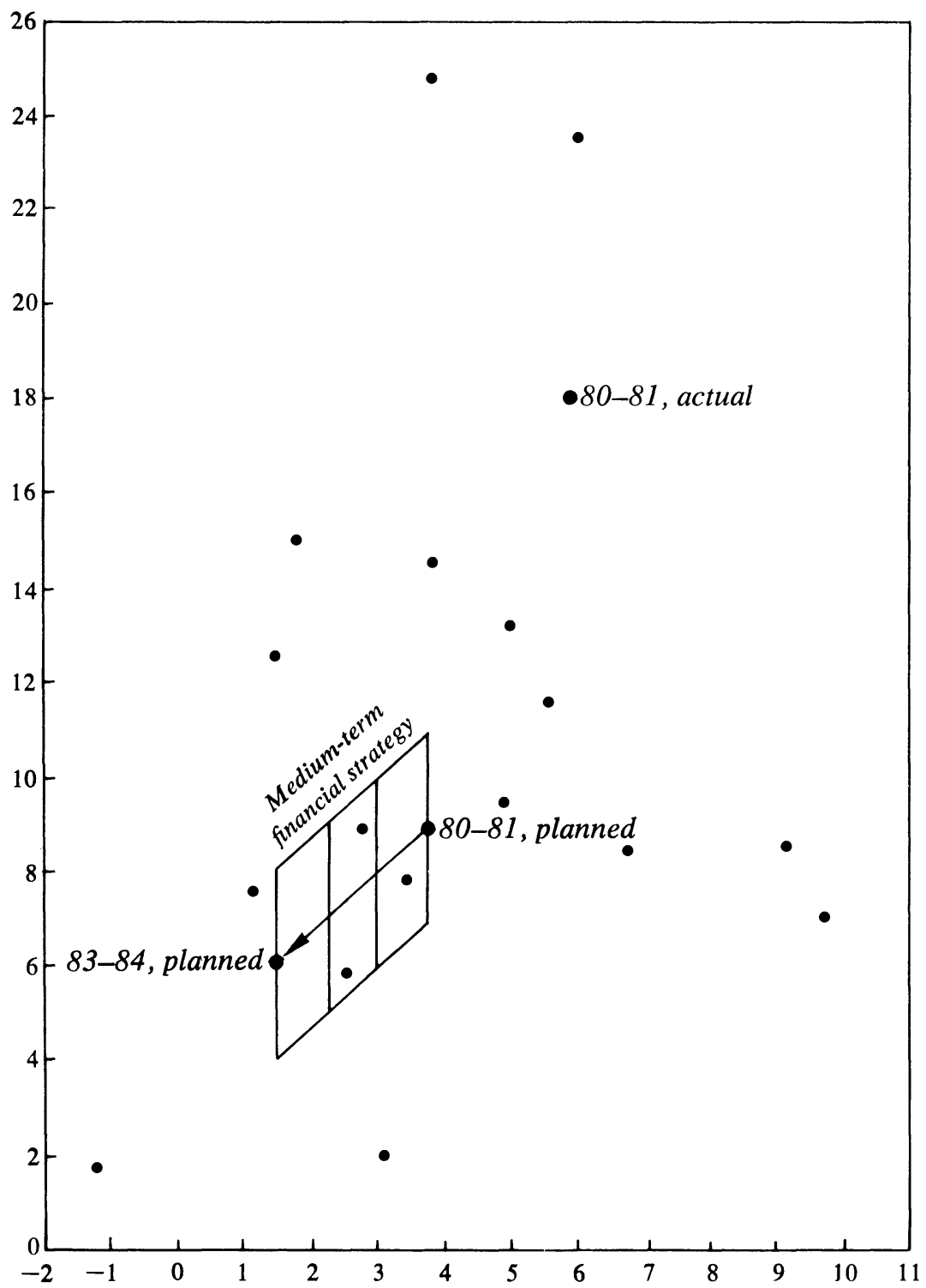

Government borrowing as a percent of gross domestic product (PSBR/GDP)

Sources: Based on the figure presented in Monetary Policy, Third Report from the House of Commons Treasury and Civil Service Committee, sess. 1980-81 (HMSO, 1981), vol. 2: Minutes of Evidence, p. 129. Data are from Economic Trends, various issues.

a. Unidentified points represent actual performance in financial years 1963-64 to 1979-80. 
Table 6. The Medium-Term Financial Strategy, March 1980 Budget Projections, Financial Years 1979-80 through 1983-84

Billions of pounds sterling, 1979-80 prices, unless otherwise specified

\begin{tabular}{lccccc}
\hline & & \multicolumn{4}{c}{ Four-year plan } \\
\cline { 5 - 6 } Indicator & $1979-80^{\mathrm{a}}$ & $1980-81$ & $1981-82$ & $1982-83$ & $1983-84$ \\
\hline $\begin{array}{c}\text { Range of growth of sterling } \\
\quad \text { M3 (percent per year) }\end{array}$ & $13.2^{\mathrm{b}}$ & $7.0-11.0$ & $6.0-10.0$ & $5.0-9.0$ & $4.0-8.0$ \\
$\begin{array}{c}\text { Public sector borrowing } \\
\quad \text { requirement/GDP at } \\
\quad \text { market prices (percent) }\end{array}$ & 4.8 & 3.8 & 3.0 & 2.3 & 1.5 \\
$\begin{array}{c}\text { Total general government } \\
\quad \text { expenditure }\end{array}$ & 88.7 & 88.7 & 86.9 & 84.5 & 83.9 \\
$\begin{array}{c}\text { Total general government } \\
\quad \text { receipts }\end{array}$ & 78.5 & 80.3 & 80.3 & 82.7 & 84.5 \\
$\begin{array}{l}\text { Implied fiscal adjustment }{ }^{\mathrm{d}} \\
\begin{array}{c}\text { General government borrow- } \\
\quad \text { ing requirement }\end{array}\end{array}$ & 10.2 & 8.4 & 6.6 & 4.8 & 3.6 \\
$\begin{array}{c}\text { Public sector borrowing } \\
\text { requirement }\end{array}$ & 9.5 & 7.1 & 6.0 & 4.2 & 3.0 \\
\hline
\end{tabular}

Source: United Kingdom, Financial Statement and Budget Report, 1980-81, tables 5, 6, 8, 9, pp. 16-19. The factor used to convert the data to $1979-80$ prices is 1.19 and is based on the average conversion factor used in evidence to the Treasury Committee. See the definition of sterling M3 in table 5, note a.

a. Budget time estimates.

b. Actual growth of money over the financial year.

c. Total general government expenditure equals general government expenditure in cost terms, plus interest payments, less allowances for the special sale of assets for shortfall, plus a national income accounts adjustment.

d. The extent to which the planned general government borrowing requirement would allow tax cuts or spending increases in 1982-83 and 1983-84.

e. Total general government expenditure minus total general government receipts plus implied fiscal adjustment. The difference between the general government borrowing requirement and the public sector borrowing requirement is the amount of public corporation borrowing from the private sector and overseas.

but also in the projected paths for government spending and taxation taken separately. With cuts of about 1 percent a year in the volume of expenditure by the central government and local authorities over a fouryear period, together with rising revenues from North Sea oil, the government planned to cut the level of direct taxation while remaining within the PSBR limits already described. Future income tax cuts are apparently to be made only as the flow of taxes on North Sea oil revenues builds up.

In table 6 we show the details of the MTFS as it was announced in 1980 , revalued to $1979-80$ prices. ${ }^{36}$ The so-called fiscal adjustment is the

36. The revenue projections are made on the conventional assumption of constant indexed tax rates and allowances at current (1980-81) levels; they basically reflect assumptions about GDP growth. 
Table 7. Revised Medium-Term Financial Strategy, March 1981 Budget Projections, Financial Years 1979-80 through 1983-84

Billions of pounds sterling, 1979-80 prices, unless otherwise specified

\begin{tabular}{|c|c|c|c|c|c|}
\hline \multirow[b]{2}{*}{ Indicator $^{\mathrm{a}}$} & \multirow[b]{2}{*}{$1979-80$} & \multirow[b]{2}{*}{$1980-81^{\mathrm{b}}$} & \multicolumn{3}{|c|}{ Three-year plan } \\
\hline & & & $1981-82$ & $1982-83$ & $1983-84$ \\
\hline $\begin{array}{l}\text { Range of growth for sterling } \\
\text { M3 (percent per year) }\end{array}$ & $13.2^{c}$ & $18.0^{\mathrm{c}}$ & $6.0-10.0$ & $5.0-9.0$ & $4.0-8.0$ \\
\hline $\begin{array}{l}\text { Public sector borrowing } \\
\text { requirement/GDP at } \\
\text { market prices (percent) }\end{array}$ & 5.0 & 6.0 & 4.3 & 3.3 & 2.0 \\
\hline $\begin{array}{l}\text { Total general government } \\
\text { expenditure }\end{array}$ & 88.8 & 91.5 & 91.5 & 90.0 & 87.5 \\
\hline $\begin{array}{l}\text { Total general government } \\
\text { receipts }\end{array}$ & 78.4 & 79.5 & 82.5 & 84.0 & 85.0 \\
\hline North Sea tax revenues & 2.3 & 3.3 & 4.5 & 4.8 & 5.3 \\
\hline Implied fiscal adjustment & $\ldots$ & $\ldots$ & $\ldots$ & 1.0 & 2.0 \\
\hline $\begin{array}{l}\text { General government borrow- } \\
\text { ing requirement }\end{array}$ & 10.4 & 12.0 & 9.0 & 7.0 & 4.5 \\
\hline $\begin{array}{l}\text { Public sector borrowing re- } \\
\text { quirement }\end{array}$ & 9.9 & 11.5 & 8.0 & 6.5 & 4.0 \\
\hline
\end{tabular}

Source: United Kingdom, Financial Statement and Budget Report, 1981-82, tables 5, 6, 7, 8, pp. 16-18. See the definition of sterling M3 in table 5, note a.

a. See table 6 , notes $\mathrm{c}$ through $\mathrm{e}$.

b. Budget time estimates.

c. Actual growth of money over the financial year.

amount by which the government believed it could cut taxes or increase government spending while still achieving the sort of PSBR levels that would be consistent with its planned monetary growth. The PSBR projections are given in the last line of the table; they are derived from the balance of general government expenditure, allowing for the fiscal adjustment, together with an estimate of public corporation borrowing from the private sector and overseas residents. Real government expenditure planned for 1983-84, as a proportion of its level in 1979-80, reveals a planned 5 percent cutback. Planned tax receipts, however, are rising by more than 7 percent over this interval (although this drops to about 2 percent if the fiscal adjustment is assumed to take the form of tax cuts).

In table 7 the revised MTFS as presented in the March 1981 budget is shown, with the expected revenues from North Sea oil and gas now explicitly given. As can be seen by comparing tables 6 and 7, the plan for 1980-81 to keep real government spending steady was not fulfilled, as 
real spending rose by about 3 percent, and the revised plans for 1983-84 raised the target level of government spending by about 4 percent. On the other hand, tax receipts for 1980-81 failed to grow as expected; instead of increasing by 2.3 percent, they grew by 1.4 percent in real terms. The end-of-period projection for taxes is also revised upward by slightly less than 1 percent. But with the smaller fiscal adjustment-that is, with less scope for additional tax cuts or spending increases in future yearsthe rise in taxes net of the adjustment is expected to be considerably larger than before, an increase of 5.9 percent by $1983-84$ in real terms. ${ }^{37}$ Since the GDP forecast for 1983-84 was reduced by about 1.5 percent between the two budgets, the expected increase in the ratio of taxes to GDP will be even more marked. The taxes include a growing volume of receipts from North Sea oil that is expected to increase from 2.3 billion pounds sterling in $1979-80$ to 5.3 billion pounds in $1983-84$ at $1979-80$ prices.

As a consequence of the overshooting of the PSBR target in 1980-81 and the revisions already described, the PSBR is expected to be 2 percent of GDP in 1983-84 instead of 1.5 percent as before. The monetary target ranges are left intact, but because these are expressed as growth rates and the money supply overshot its target in 1980-81, starting from the new, higher base leaves the monetary target higher than before.

\section{THE MONETARY SQUEEZE}

The role played by restrictive monetary policy is central to our interpretation of the current depression. We believe that the authorities intended financial factors to be restrictive, that this was widely appreciated by operators in financial markets, and that the authorities succeeded in what they intended despite the overshooting of the broad money-target range, which some observers cite as evidence that monetary policy has been lax.

The four-year declining target range for sterling M3 shown in table 6 documents the government's intentions to have a restrictive monetary policy. Expectations obviously cannot be documented directly but it was the virtually unanimous opinion of financial analysts and commentators in 1979-80 that the incoming government was committed to a policy of

37. Projected 1983-84 receipts of 85 billion pounds sterling minus the fiscal adjustment of 2 billion pounds are 5.9 percent above the level of receipts of 78.4 billion pounds shown for 1979-80 in table 7 . 
bringing down inflation through monetary restraint. Although the Chancellor planned to achieve his monetary targets "without excessive reliance on interest rates," the minimum lending rate was raised in June 1979 and again in November 1979, reaching 17 percent, which was almost three points higher than the yield on twenty-year government bonds. The 10 percent rise of the effective exchange rate of sterling during 1980 was cited as an indirect indication of tight financial conditions by the Bank of England. ${ }^{38}$

Broader evidence that monetary policy was, in fact, restrictive is found in the growth rate of the narrower monetary aggregates, in real interest rates confronting business, and in general indicators of financial stringency in the business sector.

Table 8 shows how narrowly defined real money balances, measured by $\mathrm{M} 1$ or by the monetary base, have contracted sharply ever since 1979:3. These real declines came as policy slowed growth in the nominal aggregates while inflation continued and, indeed, rose as a consequence of the rise in value added tax, the wage explosion, and the rise in oil prices. Real sterling M3 also contracted in the initial quarters of the new government, but started growing again after mid-1980.

Various nominal interest rates in table 9 show how the Bank of England raised the minimum lending rate sharply in late 1979 and how market rates rose with it; but then the bank brought rates down quite promptly in late 1980, despite the overshooting of the sterling M3 target at that time. However, when the 1981-82 target was overshot, monetary policy let interest rates increase substantially, and Treasury bill rates rose to more than 15 percent by October 1981.

The "real" interest rates that correspond to these developments depend on who is paying them and for what purpose. Various measures of price increase are compared in the last four columns of table 9 . The rate of increase of the retail price index, shown in column 4, includes the increase in the value added tax, which does not accrue to private firms. A better idea of inflation from the supplier's point of view is the GDP deflator at factor cost, shown in column 6 . But even subtracting the rise in the GDP deflator from the interest rate gives a misleading impression of real borrowing costs for the nonoil private sector in the United Kingdom. Given the United Kingdom's rapid move toward self-sufficiency in oil and 


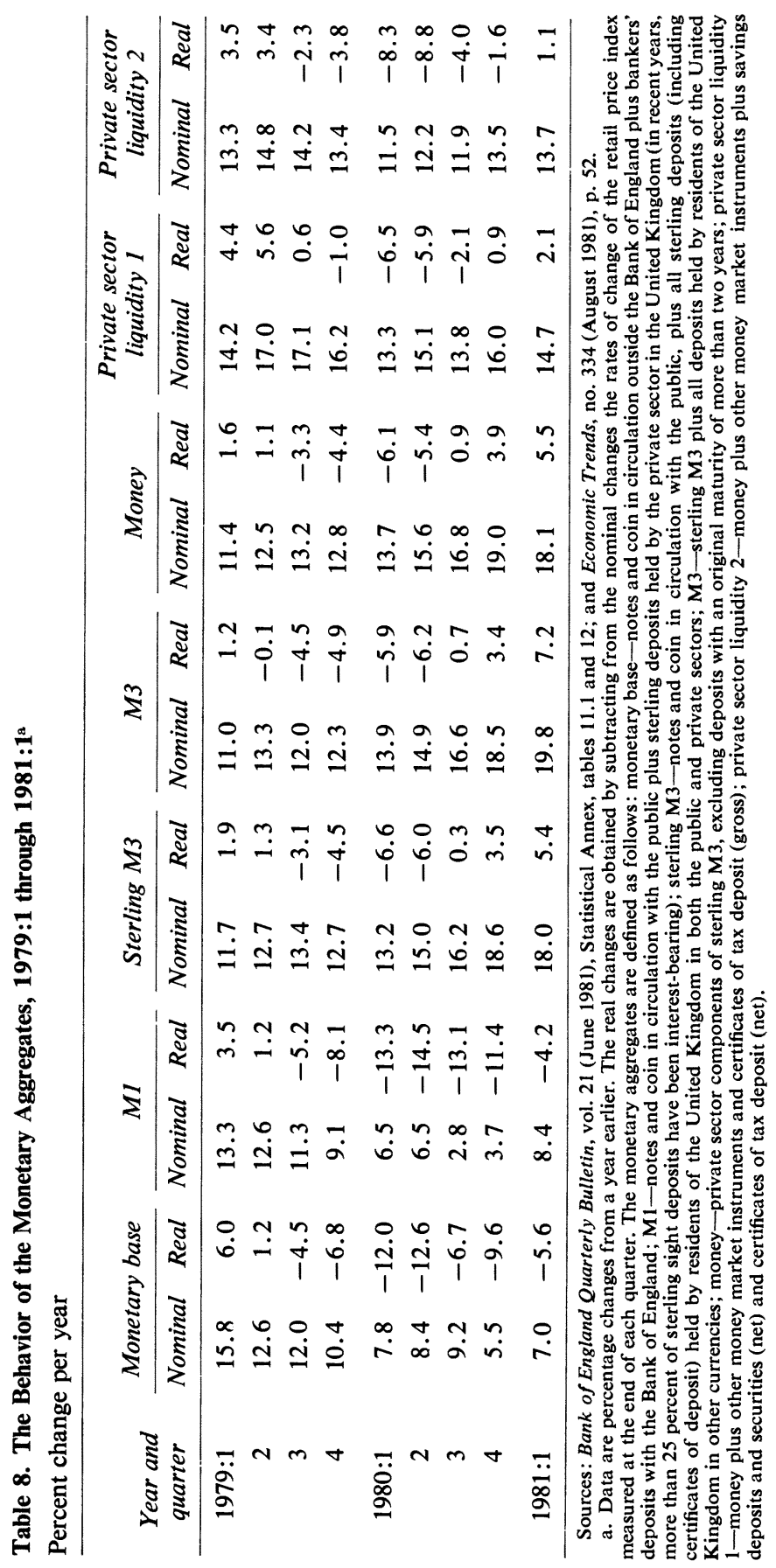




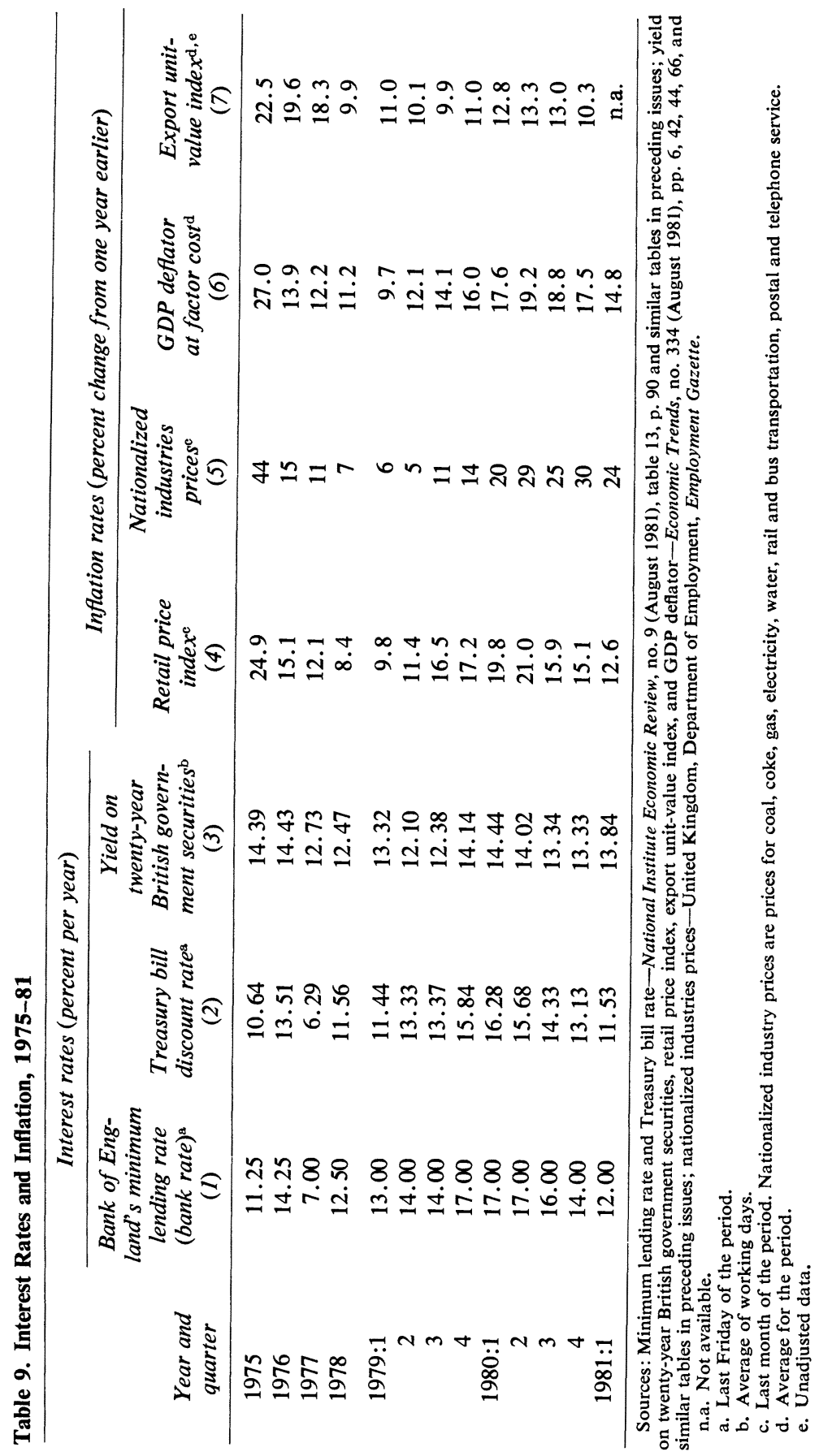


the importance of the nationalized industries, much of the rise in the GDP deflator was due to oil prices increases and to the substantial increases in nationalized industry prices shown in column 5 . The export unit-value index in the United Kingdom, shown in column 7, illustrates the behavior of prices actually received by internationally exposed firms. It is because of relatively low price increases like these that many firms have had to absorb sharply increasing sterling wage costs and the high nominal interest rates shown in the first column: by this measure, monetary policy has certainly been restrictive.

The financial difficulties that confronted the business sector as a consequence of the restrictive policy and the business slump it induced are evident in a range of financial measures. Industrial and commercial companies (ICCs) in the United Kingdom experienced a sharp increase in their financial deficits and net borrowing requirements in 1979-80. They have had to cut production and inventories, shed labor, and reduce hours worked. Statistics on total profits understate the weak profitability of most firms because one-third of all ICC profits in 1980 were attributable to North Sea companies. ${ }^{39}$

The real profitability of companies aside from North Sea activities, as measured by the pretax real rate of return on their trading assets, fell to a record low of 2.9 percent in 1980, as shown in table 10, column 7. This compares with an average of 5.5 percent from 1974 to 1979 , the period after the first oil price explosion, and an average of 10.0 percent from 1963 to $1973 .^{40}$

A similar story is told by the valuation ratio (Tobin's $q$, the ratio of the average rate of return on existing trading assets to the cost of capital, both expressed in posttax real terms), shown in table 10 for all ICCs, including North Sea oil. After dropping sharply below unity in 1974, $q$ reached a plateau of approximately 0.9 for the three years to 1979 , but it has fallen sharply in 1980 to the same low level as in 1974, one that "represents only a very weak inducement to invest." ${ }^{11}$ The liquidity ratios and the pace of bankruptcies and liquidations shown in the table also reveal the financial stringency produced by the MTFS.

The growth targets for sterling M3 over the years since 1976 are shown

39. See United Kingdom, Her Majesty's Treasury, Economic Progress Report, no. 136 (August 1981).

40. Bank of England Quarterly Bulletin, vol. 21 (June 1981), p. 228.

41. Ibid., p. 229. 


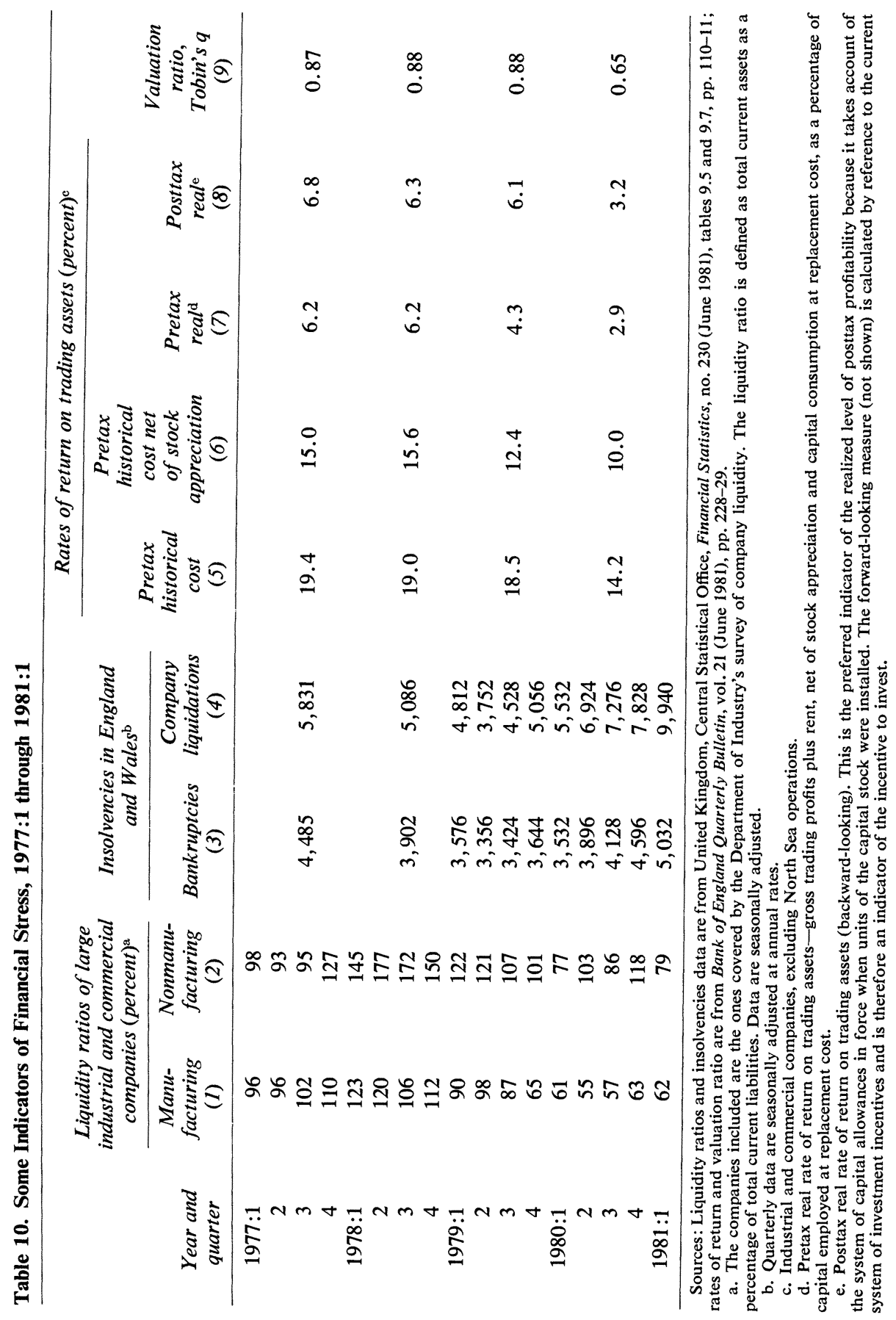


Table 11. Targets and Actual Growth of Sterling M3, 1976-82 ${ }^{\text {a }}$

\begin{tabular}{llcc}
\hline Date target set & \multicolumn{1}{c}{ Period of target } & $\begin{array}{c}\text { Sterling M3 } \\
\text { target (annual } \\
\text { growth rate, } \\
\text { in percent) }\end{array}$ & $\begin{array}{c}\text { Sterling M3 } \\
\text { actual (annual } \\
\text { growth rate, } \\
\text { in percent) }\end{array}$ \\
\hline December 1976 & Twelve months to April 1977 & $9-13^{\mathrm{c}}$ & 7.2 \\
March 1977 & Twelve months to April 1978 & $9-13^{\mathrm{c}}$ & 15.9 \\
April 1978 & Twelve months to April 1979 & $8-12$ & 10.9 \\
November 1978 & Twelve months to October 1979 & $8-12$ & 13.2 \\
June 1979 & Ten months to April 1980 & $7-11$ & 10.2 \\
November 1979 & Sixteen months to October 1980 & $7-11$ & 17.6 \\
March 1980 & Fourteen months to April 1981 & $7-11$ & 19.6 \\
March 1981 & Fourteen months to April 1982 & $6-10$ & $16.9^{\mathrm{d}}$ \\
\hline
\end{tabular}

Sources: Target sterling M3 is from Memoranda on Monetary Policy and Public Expenditure, House of Commons Treasury and Civil Service Committee, sess. 1979-80 (HMSO, 1980), p. 6: and United Kingdom, Financial Statement and Budget Report, 1980-81 and 1981-82, p. 16 in both. Actual sterling M3 is from Bank of England Quarterly Bulletin, vol. 20 (September and December 1980), and vol. 21 (September 1981), table 11.1.

a. For a definition of sterling M3 see table 8, note a.

b. From seasonally adjusted data.

c. The range is consistent with the domestic credit expansion limit.

d. To August 1981 at an annual rate, as estimated in Bank of England Quarterly Bulletin, vol. 21 (September 1981), p. 327.

in table 11, along with the actual growth rates. The incoming government reduced the target range from 8-12 percent to 7-11 percent in June 1979, and then "rolled this target range forward" twice, in November 1979 and March 1980. By mid-1980, however, sterling M3 was well above its target range. Although this monetary aggregate was rebased in the March 1981 budget, it has been exceeding its new target path in the course of this year also. ${ }^{42}$

The ending of the corset scheme added to sterling M3, and its 18 percent annual growth rate during the year ending 1981:1 probably exceeded the growth rate that would have occurred without that change by 3 to 4 percentage points. The two other broad measures of private sector liquidity grew by well over 13 percent in the same period. Clearly the broader aggregates behaved differently from their narrower counterparts, and, somewhat ruefully, the Bank of England noted that the growth of M1 was "perhaps broadly in line with the path that might have been envisaged had there been a formal target for this aggregate." ${ }^{43}$

42. However, recent figures are thought to be badly distorted by the civil servants' dispute, with a proportion of uncollected taxes lodged with the banking system raising sterling M3 growth. See Bank of England Quarterly Bulletin, vol. 21 (September 1981), p. 327.

43. Bank of England Quarterly Bulletin, vol. 21 (March 1981), p. 18. 
In explaining why sterling M3 has not adequately reflected the stringency of financial conditions, the Bank of England commented: "The onset of the recession ... has had a large effect on the pattern of financing in the economy. This change of pattern, probably in part temporary, may explain a good deal of the behaviour of sterling M3. The recession has not only enlarged the PSBR but, along with the high exchange rate and high wage settlements, has exacerbated the financial difficulties of companies, particularly those in manufacturing. Personal incomes have benefited from large wage increases and the high exchange rate, and personal savings have grown. Companies have continued to be almost exclusively dependent for external finance on the banks-which have thus provided a channel whereby the enlarged surplus of the personal sector has been on-lent to companies." 44

Given the ability of the banking system, freed from corset regulations, to attract the necessary deposits by competitive interest rates, the Bank of England clearly sees the broad monetary aggregates as determined in large part by the demands for credit by companies and the government. It argues that, far from demonstrating the laxity of monetary policy, the behavior of sterling M3 has reflected the squeeze on the company sector. The ICCs, caught between rising wages and a strong exchange rate, which prevented them from simply passing on their cost increases, cut back production and borrowed heavily from the banks to finance their borrowing needs. The chosen broad money target, whose attainment was meant to lead inflation expectations downward and to reinforce the credibility of the government's policy, was perversely endogenous, tending to rise as companies borrowed to stay in business.

\section{Fiscal Policy}

The government's desire to control the PSBR means that it has to respond with changes in spending programs and tax and transfer schedules to changes in the level of economic activity that would otherwise alter its deficit. In a closed economy such overriding of the automatic fiscal stabilizers will tend to magnify the response of output to exogenous demand shocks.

44. Bank of England Quarterly Bulletin, vol. 20 (December 1980), p. 406. 
For an open economy, in the familiar Mundell model with perfect capital mobility, static expectations, a floating exchange rate, and a predetermined domestic price level, there is no risk of output-destabilizing consequences from fiscal actions aimed at balancing the budget or from any shock to private demand. A shock to aggregate demand leads to a change in the exchange rate sufficient to restore the initial level of output, which is determined entirely by the money stock. However, the conditions for such complete "crowding out" through exchange rate movements are extreme and unrealistic. Branson and Buiter have recently shown this by allowing for the effect of the exchange rate on the general price level and thus on the real stock of money balances, for imperfect substitutability between domestic and foreign interest-bearing assets, for external wealth adjustment through the current account deterioration resulting from a fiscal expansion, and for rational expectations in the foreign exchange market. ${ }^{45}$

With any or all of these modifications to the simple Mundell model, varying the level of public spending or changing tax-transfer schedules to match variations in the inflow of taxes net of transfers will affect output even in an open economy with a floating exchange rate and a high degree of capital mobility, although the magnitude of the effect is likely to be less than that in a closed economy. Conventional measures of the stance of fiscal policy therefore continue to be important in interpreting the behavior of output.

As shown in table 6, the government planned to keep its expenditure constant in real terms in the first year of the MTFS, while increasing its receipts by enough to cut the PSBR/GDP ratio by 1 percentage point. A recession was anticipated, so taxes on income and expenditure were not expected to be buoyant; rising North Sea oil taxes were expected to contribute half of the rise in taxes. As table 7 shows, expenditure actually grew quite sharply - by 3 percent in real terms-and taxes proved less buoyant than expected, so that the PSBR rose by 1 percent relative to GDP.

The observation that the PSBR overshot its target path and rose relative to GDP rather than falling as planned might be taken as a sign that

45. William H. Branson and Willem H. Buiter, "Monetary and Fiscal Policy with Flexible Exchange Rates," Discussion Paper 95-81 (University of Bristol, 1981 ). 
Table 12. Cyclically Adjusted Public Sector Borrowing Requirement, Financial Years 1978-79 through 1982-83 ${ }^{\mathrm{a}}$

Percent unless otherwise specified

\begin{tabular}{|c|c|c|c|c|c|}
\hline Item & $1978-79$ & $1979-80$ & $1980-81$ & $1981-82$ & $1982-83$ \\
\hline $\begin{array}{l}\text { Public sector borrowing } \\
\text { requirement (billions of } \\
\text { pounds sterling) }\end{array}$ & 9.2 & 9.9 & 13.3 & $(9.5)$ & $(8.8)$ \\
\hline $\begin{array}{l}\text { Public sector borrowing } \\
\text { requirement/GDP }\end{array}$ & 5.5 & 5.0 & 5.9 & $(3.8)$ & $(3.2)$ \\
\hline Cyclical adjustment $\mathrm{t}^{\mathrm{b}}$ & 0.0 & 0.0 & -3.3 & -5.3 & n.a. \\
\hline $\begin{array}{l}\text { Cyclically adjusted public } \\
\text { sector borrowing require- } \\
\text { ment/GDP }\end{array}$ & 5.5 & 5.0 & 2.6 & $-1.5^{\mathrm{c}}$ & n.a. \\
\hline \multicolumn{6}{|l|}{ Memoranda } \\
\hline GDP gap ga $^{\mathrm{d}}$ & 0.0 & 0.0 & 5.0 & 7.0 & n.a. \\
\hline $\begin{array}{l}\text { Unemployment (average for } \\
\text { fiscal year) }\end{array}$ & 5.6 & 5.4 & 7.8 & $(10.9)$ & n.a. \\
\hline Inflatione & 8.8 & 17.8 & 11.4 & n.a. & n.a. \\
\hline \multicolumn{6}{|l|}{$\begin{array}{l}\text { Planned public sector borrow- } \\
\text { ing requirement/GDP }\end{array}$} \\
\hline March 1980 & $\ldots$ & $\ldots$ & 3.8 & 3.0 & 2.3 \\
\hline March 1981 & $\ldots$ & $\ldots$ & $\ldots$ & 4.3 & 3.3 \\
\hline
\end{tabular}

Sources: Public sector borrowing requirement in pounds sterling-Bank of England Quarterly Review, vol. 21 (June 1981), Statistical Annex, table 11.3; and National Institute Economic Review, no. 96 (May 1981), p. 27 for forecasts; public sector borrowing requirement/GDP, GDP gap, and unemploymentNational Institue of Economic Research: inflation-Economic Trends, no. 337 (November 1981), p. 10; planned public sector borrowing requirement/GDP-United Kingdom, Financial Statement and Budget Report, 1980-81 and Financial Statement and Budget Report, 1981-82.

n.a. Not available.

a. The numbers in parentheses are forecasts.

b. Cyclical adjustment is one-half GDP gap plus one-third (unemployment rate - 5.4).

c. Surplus.

d. Assuming 1.75 percent per year as trend GDP.

e. Growth in the consumers' expenditure deflator, first quarter to first quarter.

fiscal policy was expansionary in 1980-81; such an impression is supported by published figures of the National Institute of Economic and Social Research showing a 2.4 percent increase in the "demand-weighted" deficit as a percentage of GDP. ${ }^{46}$ However, these ex post measures of the stance of fiscal policy are misleading and must both be corrected for the impact of the business downturn.

46. National Institute Economic Review, no. 96 (May 1981), p. 12. The weighted budget surplus or deficit figures reflect the direct GDP-creating or GDP-reducing effect of the various categories of expenditures and receipts. 
The cyclical adjustments to the PSBR itself are shown in table 12. As a simple rule of thumb, which appears to be consistent with the more elaborate procedures used by the National Institute of Economic and Social Research, we have assumed that taxes automatically decline $1 / 2$ percentage point of GDP for every 1 point that GDP falls beneath its trend, and that induced expenditure rises by $1 / 3$ of a point of GDP for every 1 point that unemployment increases.

Starting with GDP at its last peak in fiscal 1979-80 and assuming a trend growth of GDP of $13 / 4$ percent a year (which is halfway between the high and low assumptions made at the National Institute) implies a gap of 5 percent for 1980-81, and this is associated with an increase of about 2.4 points in the rate of unemployment. This leads to a "cyclical correction" of 3.3 percentage points in the PSBR/GDP ratio, indicating that the PSBR would have fallen to less than 3 percent of GDP in 198081 if the economy had grown on trend, keeping unemployment constant. ${ }^{47}$

For the current fiscal year the cyclical correction is estimated to be 5.3 percentage points of GDP, which exceeds the planned deficit (and the deficit projected by the National Institute), implying a cyclically adjusted surplus. The GDP gap for 1981-82, using the GDP forecast made by the National Institute, is estimated to be 7 percent. This would ordinarily be associated with a rise of the unemployment percentage by about half as much from 1979-80 according to the version of Okun's law used in the United Kingdom, which worked well in 1980-81. But instead of rising by another point as the GDP gap widens in 1981, unemployment is forecast to increase by three points.

The government has no plans to stabilize the economy along its potential growth path. Therefore, as Okun himself reasons, one would not in such circumstances expect the sort of labor hoarding that his law describes. ${ }^{48}$ The rise in unemployment this year may thus be a demonstration that Okun's law is subject to the Lucas critique-that the behavior of the private sector varies according to its participants' perceptions of the government's policy rules.

47. This correction exceeds that described in the Bank of England Quarterly Bulletin, vol. 20 (September 1980), p. 268, in which the PSBR/GDP ratio is assumed to rise by just under half a percentage point for every point that GDP falls beneath its trend.

48. Arthur M. Okun, Prices and Quantities: A Macroeconomic Analysis (Brookings Institution, 1981), p. 228. 
Table 13. Changes in the Public Sector Borrowing Requirement, Financial Years 1979-80 through 1981-82 ${ }^{a}$

Percentage points

\begin{tabular}{lrrr}
\hline \multicolumn{1}{c}{ Item } & $1979-80$ & $1980-81$ & $1981-82$ \\
\hline $\begin{array}{l}\text { Change in the public sector borrowing } \\
\text { requirement/GDP ratio }\end{array}$ & -0.5 & 0.9 & -2.1 \\
$\begin{array}{l}\text { Change in the cyclically adjusted public sector } \\
\quad \text { borrowing requirement/GDP ratio }\end{array}$ & -0.5 & -2.4 & -4.1 \\
$\begin{array}{l}\text { Change in the weighted deficit/GDP ratio } \\
\begin{array}{l}\text { Change in the weighted deficit/GDP ratio } \\
\quad \text { after cyclical adjustment }\end{array}\end{array}$ & -0.3 & 2.4 & -2.5 \\
\hline
\end{tabular}

Sources: Table 12, except for change in the weighted deficit/GDP ratio, which is from National Institute Economic Review, no. 96 (May 1981), table 6, p. 12.

a. A minus symbol indicates a reduction in the deficit as a percent of GDP.

b. The change in the weighted deficit/GDP ratio after cyclical adjustment is calculated from the cyclical adjustment in table 12 .

Four measures of the change in the fiscal balance are shown in table 13 for 1979-80 and for the first two years of the MTFS. The changes in the PSBR/GDP ratio are shown first, before and after adjusting for the cycle in the manner just described. The third row shows the changes in the demand-weighted deficit as a percent of GDP, as published by the $\mathrm{Na}$ tional Institute. After little change in 1979-80, the weighted deficit was estimated to rise by 2.4 percent of GDP in the first year of the MTFS; but it is forecast to fall by 2.5 points in 1981-82. These changes are to a large extent endogenous, however, with extra spending and less taxation reflecting the recession. When they, too, are corrected to remove the contribution of the automatic stabilizers, we find that, after a small contraction in 1979-80, the cyclically adjusted, demand-weighted deficit showed little change in 1980-81 when the government overshot its planned spending targets, but will contract sharply if, as in the National Institute's forecast, the government achieves its PSBR targets in the second year of the MTFS. ${ }^{49}$

The pessimism of the government's own assumptions as to the future path for output made in setting the course of fiscal policy is clear from the 1980-81 and 1981-82 budget reports. In the first document the Chancellor made the deliberately cautious assumption that real GDP, after falling by 2 percent in calendar year 1980, would then grow at an average rate of 1 percent a year during the next three years; in the second docu-

49. National Institute Economic Review, no. 96 (May 1981), p. 27. 
ment, written when it was becoming more likely that there was to be little if any growth in calendar year 1981, the average growth rate projected for $1980-83$ was reduced to $1 / 2$ percent a year. ${ }^{50}$

Thus the level of real GDP assumed for 1983 in designing the course of fiscal policy (with the PSBR supposed to fall to only 2 percent of GDP in 1983-84) is below the level of GDP in 1979, despite the fact that oil and gas production is expected to grow from 21/4 percent of GDP in 1979 to $4 \frac{1}{2}$ percent of GDP during the four years in question, thus contributing about $1 / 2$ percent a year to the growth of GDP. ${ }^{51}$

It is thus no surprise to find, as in table 13, that the net contribution of the government's programs to the growth of demand will, after the overshooting of the PSBR targets is checked, fall far short of the economy's trend rate of growth. But by the same token, the authorities should expect unemployment to rise sharply under the MTFS, which assumes a growing shortfall of actual GDP relative to its potential trend.

The principal reason given for the design of the fiscal policy appears to be the desire to avoid crowding out private investment if borrowing were to rise relative to GDP and the government adhered to its monetary targets. The ratio of debt to GDP is affected not only by new borrowing but also by the change in the real value of the outstanding stock. The Bank of England does publish figures showing the change, due to inflation, in the real value of the existing stock of debt, valued at par. This adjustment for inflation is subtracted from the nominal PSBR to give what the Bank of England refers to as the real PSBR. ${ }^{52}$ Because the par value of government debt is approximately half that of GDP, the inflation adjustment, expressed as a percent of GDP, is half a percentage point for each point of inflation. The Bank of England is, however, reluctant to ascribe much significance to the year-by-year timing of these adjustments, so we have not included them in our calculations above. In table 12, however, we show the rate of inflation over the financial year so that the reader will have some idea of what the adjustment would be.

In discussing its findings over a number of years, the Bank of England observes: "In the early 1970s nominal public sector borrowing was more than offset by the erosion of the real value of existing liabilities, so

50. United Kingdom, Financial Statement and Budget Report, 1980-81, p. 18; and Financial Statement and Budget Report, 1981-82, p. 17.

51. Economic Progress Report, no. 131 (March 1981), p. 14.

52. For a comprehensive discussion see C. T. Taylor and A. R. Threadgold, “' Real' National Saving and Its Sectoral Composition," Discussion Paper 6 (Bank of England, 1979). 
that the public sector tended to be a 'real' net lender. But in recent years [1976-78], in part reflecting the depressed economy, the public sector has on average tended to be a small 'real' borrower. This finding is consistent with the decline in nominal national debt outstanding relative to current price GDP up to the mid-1970s, and the rough stability of this relationship thereafter." ${ }_{53}$

Although it appears from table 12 that the inflation-adjusted PSBR would be in deficit for 1980-81 when the PSBR target was exceeded, this is unlikely this financial year with a PSBR of between 3 and 4 percent of GDP and inflation above 10 percent. Indeed, it appears quite likely that the "real" PSBR would be in surplus over the future of the MTFS, despite the recession. Thus, even if one believed his theoretical argument, the facts do not support Thomas Sargent's view that the MTFS is not credible essentially because it involves a forecast of deficits that will raise the ratio of debt to GDP and debt to money and thus will force the government to depart from its monetary rule. ${ }^{54}$ On the contrary, by expressing a target for nominal PSBR relative to GDP at a time of gradually slowing inflation, the MTFS promised to reduce the ratio of debt to GDP and to money as the government becomes a "real" lender! 55

Not only is the government seriously misjudging the degree of crowding out attributable to its deficit, but also, to the extent that the capital losses on government debt affect aggregate demand as people save to restore their asset holdings-what Tobin calls the dynamic Pigou effectthe demand effects discussed above are too optimistic. ${ }^{56}$ Demand weighting the "real" PSBR would make fiscal policy more restrictive than it appears on the basis of the nominal PSBR.

Finally, going beyond the aggregate data, we argue below that the government's failure to cut taxes promptly in response to the rise in oil prices in OPEC-2 (the second OPEC oil price shock) meant that incomes were transferred from the nonoil sector to the oil companies in a way that

53. Bank of England Quarterly Bulletin, vol. 21 (June 1981), p. 232.

54. See Thomas J. Sargent, "Stopping Moderate Inflation: The Methods of Poincaré and Thatcher" (University of Minnesota and Federal Reserve Bank of Minneapolis, May 1981); and Sargent and Neil Wallace, "The Fight against Inflation: How Much Can the Fed Do on Its Own?" (University of Minnesota and Federal Reserve Bank of Minneapolis, rev. August 1981).

55. For further discussion see Marcus Miller, "The Medium Term Financial Strategy: An Experiment in Co-ordinating Monetary and Fiscal Policy," Fiscal Studies, vol. 2 (July 1981), pp. 50-60.

56. James Tobin, "Keynesian Models of Recession and Depression," American Economic Review, vol. 65 (May 1975, Papers and Proceedings, 1974), pp. 195-202. 


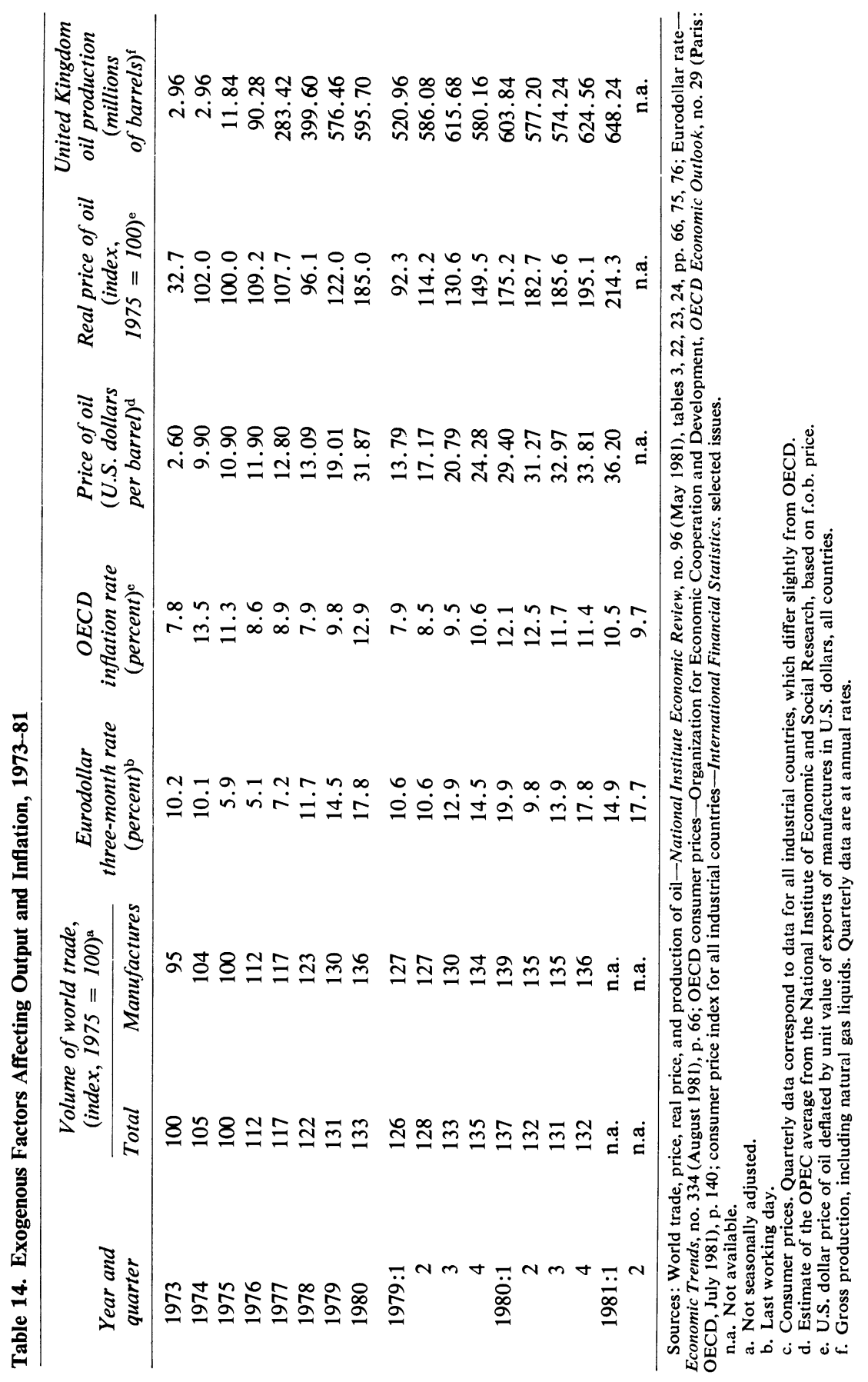


intensified the monetary squeeze on the company sector and the depth of the recession.

\section{Exogenous Factors}

The new Thatcher policies were imposed at a time when the external environment became unfavorable to price stability and growth. Table 14 summarizes some of the developments that were important but largely exogenous to United Kingdom policy. The dollar price of oil rose by 45 percent between 1978 and 1979 and by a further 68 percent between 1979 and 1980. The price of oil relative to traded manufactures rose 27 percent and 52 percent in these two years. World trade grew by 7 percent between 1978 and 1979 but only 1.5 percent between 1979 and 1980 . More relevant to the United Kingdom, the growth of world trade in manufactures slowed from 5.7 percent to 4.6 percent in these two years. Starting in 1979, the Eurodollar three-month interest rate fluctuated wildly around an upward trend.

Although the unfavorable development in world trade and world interest rates undoubtedly contributed to the slump in output of the United Kingdom's economy, countries such as France and Germany faced these same external constraints without experiencing a recession of comparable magnitude. Also, if a decline in world demand for the output of the United Kingdom had been the major cause of its depression, it should not have led to the sharp appreciation of sterling and thus the loss of competitiveness that actually occurred. The increase in world inflation during 1979 and 1980, as measured by the OECD consumer price index, shows that other industrial economies suffered price inflation from OPEC-2, as did Britain. But this has no obvious implications for the depth of the depression in the United Kingdom.

\section{The Impact of North Sea Oil on the United Kingdom's Economy ${ }^{57}$}

The second OPEC oil price shock hit just as the United Kingdom evolved from being a large net importer of oil during most of the 1970s

57. Our analysis of the impact of oil owes a great deal to discussions with John Flemming. 
to self-sufficiency in 1980. We now examine whether, as some have argued, a major part of the loss of competitiveness of industry in the United Kingdom and the associated decline of industrial, and especially manufacturing, production in the late 1970s represents the equilibrium response to the increase of domestic oil production and prices. ${ }^{58}$ In other words, can OPEC-2 be blamed for the extraordinary slump in the United Kingdom?

It is important to distinguish between the effects on the United Kingdom's wealth resulting from the discovery of North Sea oil and the effect of increases in the oil price once that discovery was made. The discovery of oil did increase wealth once the market price exceeded extraction costs. But even on the optimistic assumption that North Sea oil has made the United Kingdom just self-sufficient in oil indefinitely, further increases in its price do not change the real value of total wealth or total income for the economy, though those increases can alter the distribution of domestic income between consumers and oil producers. Higher oil prices do increase the United Kingdom's income and wealth vis-à-vis countries that are net oil importers and lower them relative to net oil exporters.

\section{OIL AS WEALTH}

The qualitative features of the equilibrium responses to an oil discovery are familiar. Compared to what its position would have been without domestic oil and with oil priced at its 1980 level, North Sea oil represents a transfer from nature to the United Kingdom equal to the present value of the oil rents (revenue net of extraction costs) earned in the North Sea. Based on some illustrative revenue figures provided by Forsyth and Kay, the permanent income equivalent of these oil rents may amount to about 3 percent of GDP in $1980 .{ }^{59}$

Part of this increase in permanent income arising from oil discovery will be spent on domestic nontraded goods and on domestic tradables that are imperfect substitutes for foreign goods. This leads to an increase in the relative price of nontraded goods and in the relative price of domestic

58. See, for example, P. J. Forsyth and J. A. Kay, "The Economic Implications of North Sea Oil Revenues," Working Paper 10 (London: Institute for Fiscal Studies, August 1980).

59. Ibid., p. 39. 
to foreign traded goods. Such a loss of competitiveness is the marketclearing, equilibrium response to an increase in the demand for domestically produced goods facing a less than perfectly elastic supply schedule. Under plausible conditions resources would be drawn from the domestic tradables sector into both the nontradables and the oil sector. While a relative contraction of production in the manufacturing sector is required if the relative price of nontradables rises, this relative decline need not necessarily be an absolute one in a growing economy.

How great a loss of competitiveness might be associated with this equilibrium response of discovery of North Sea oil? The import and export elasticities that Forsyth and Kay use to generate their "central" estimate of 17.9 percent seem very pessimistic. The "low" Forsyth and Kay estimate is 8.2 percent. ${ }^{60}$ Even this estimate, however, uses values of import and export elasticities that appear low. The boom in capital formation that came with developing the North Sea oil fields may have strengthened the pound sterling somewhat, apart from the equilibrium response, although most of this development came before the massive 1979-80 appreciation and should not have affected the exchange rate in that period.

\section{OIL AND PORTFOLIO INVESTMENT}

In the last few years sterling has reemerged as a significant part of international portfolios. The argument can be made that the discovery of domestic oil not only represents a windfall transfer from nature, but also safeguards the economy of the United Kingdom against the direct effects of certain kinds of economic calamities such as oil embargoes. (Spillover effects from less fortunate trading partners cannot be avoided in this way.) This could move the United Kingdom into a superior risk-class from the point of view of portfolio investment, lowering the required expected real rate of return on sterling portfolio investments. This portfolio shift hypothesis is consistent with the timing of the appreciation of sterling because security against disaster through self-sufficiency is achieved only when actual oil production satisfies domestic requirements.

Although it is virtually impossible to quantify this portfolio shift effect, it may well have contributed to the loss of competitiveness since 1979, but

60. Ibid., p. 30. 
it is doubtful that its contribution could be large. Together with the 8.2 percent "low" estimate of the loss of competitiveness required to equilibrate the current account that was discussed above, these two channels through which oil would affect competitiveness cannot account for much of the 50 percent loss of competitiveness that actually occurred.

\section{OIL PRICE INCREASES AND COMPETITIVENESS}

Thus far we have considered the effect on competitiveness of the United Kingdom's oil endowments, valued at 1980 oil prices. We now turn to the effect that the increase in oil prices during 1978-80 may have had. Will an increase in world oil prices lead to a loss of competitiveness for a country like the United Kingdom? Ignoring substitution in demand away from oil and other energy products, the answer would seem to depend primarily on the country's degree of self-sufficiency in oil. Net oil importers must shift resources into the tradables sector to pay for the more expensive oil. A country self-sufficient in oil should have no prima facie grounds for altering the intersectoral allocation of its resources. But, because many oil exporting nations do not have significant manufacturing sectors, an oil self-sufficient nation like Britain must, in fact, shift resources away from tradables. We would therefore expect, as a result of OPEC-2, some deterioration of United Kingdom competitiveness vis-à-vis the net oil importers-the OECD minus Norway and Canada, and the nonoil developing countries.

\section{FISCAL ASPECTS OF OPEC-2}

The oil price increase has an important effect on the demand for capital and labor used in production and on the real wage and capital rentals that they can earn. Regardless of the country's position as an oil producer, the use of oil as an intermediate input in domestic production means that a decline in the real product wage (or marginal labor costs) is required to maintain full employment.

Real wage resistance - attempts by workers to maintain a roughly constant standard of living in line with the nation's self-sufficiency in oilwould lead to some combination of unemployment and a further squeeze in nonoil profits. This appears to have happened in the United Kingdom 
after OPEC-2. To avoid this, the appropriate fiscal response would have been a cut of employers' payroll taxes so as to lower marginal labor costs to employers to the level needed to maintain employment, without lowering the real wages demanded by workers. Such a tax cut could have been financed out of the government's current and prospective future oil revenues.

\section{OIL AS CURRENT INCOME}

With imperfect capital markets, the current flow of oil revenue assumes additional importance beyond its contribution to the present value of current and future oil revenue. It is here that the role of financial intermediation by the government during the buildup toward peak oil production becomes crucial. In the long run, most of the rents from oil will accrue to the government as tax revenue. Private agents are likely to be frustrated in their attempts to consume the permanent income equivalent of the oil revenue by their inability to borrow against the reduction in their future tax liabilities that is made possible by the oil revenues. The government could spend the additional revenue itself. But the present government's commitment to reduce public expenditure for structural reasons prevents it from following this course of action. Not subject to borrowing constraints in the capital markets, the government can remove borrowing constraints on private spending by implementing tax cuts in line with the perpetuity equivalent of its future North Sea oil revenues. However, the preoccupation with the current PSBR means that neither the government nor the private sector is spending in line with permanent income.

\section{The Causes of the Depression: A Summary}

We attribute the recent depression in the United Kingdom primarily to the effects of restrictive monetary policy, compounded by ill-designed fiscal policy. It must be recognized, however, that these contractionary policies were implemented in an unfavorable environment. The oil price increase of OPEC-2 and the slowdown in the growth of world trade, the latter to a large extent a consequence of the former, were unfavorable external shocks. Domestically, the authorities had to contend with the 
surge in wage settlements that followed the collapse of the previous Labour government's incomes policy. ${ }^{61}$

The government established the credibility of its restrictive policy stance at the start of its term of office. The perception that current and future monetary policy would be restrictive was reflected promptly in the exchange rate, interest rates, and financial markets generally, but only gradually in domestic costs, especially wages. This led to a major appreciation of the real exchange rate along the lines of the overshooting model, a rise in real interest rates, and a decline in Tobin's $q$.

The restrictiveness of the chosen limits for monetary growth was intensified by the one-time increase in the price level associated with the switch from direct to indirect taxes, a part of the government's supply-side package, and the exogenous rise in energy costs. Both these shocks came in addition to the underlying rapid rate of inflation inherited from the previous government and the acceleration of wage settlements in the public sector to which the new Thatcher government acceded.

The contractionary monetary policy was reinforced by the conduct of fiscal policy. The automatic fiscal stabilizers were overridden to an increasing extent as the authorities tried to adhere to a set of fiscal plans that called for the PSBR to decline relative to GDP. As the economy fell progressively below its potential trend, and the permanent value of the government's North Sea oil revenues was neither spent by the authorities nor returned to the nonoil private sector in the form of tax cuts, this fiscal policy grew increasingly procyclical and restrictive.

On the supply side, the oil price increase required a reduction in marginal labor costs in order to maintain the competitiveness of business and thus employment. This reduction did not take place, presumably because of real wage resistance in the labor market. The government could have achieved the required reduction in labor costs despite real wage resistance by returning its North Sea oil revenues to the private sector in the form of a cut in payroll taxes, such as the employers' national insurance surcharge.

61. The current government has belatedly recognized the importance of public sector pay. It took a hard line during the Civil Service strike in the first half of 1981 over its 7 percent pay offer, and it has established a 4 percent pay norm for the coming public sector pay round. This stance represents a major reversal of the complete disregard with which these pay increases were treated in the early days of the administration. With one-third of the labor force in the public sector, Britain will always need at least one-third of an incomes policy. 
Failure to do this has worsened competitiveness and further squeezed the profitability of the nonoil sector.

The fact that the decline in output can be largely accounted for by a decline in inventory investment deserves special comment. One possible explanation lies in the idea that it is "permanent" or long run rather than current competitiveness that determines current export performance. ${ }^{62}$ To the extent that a loss of competitiveness is expected to be transitory, as it would be in response to a nominal shock, exporters wishing to avoid the large setup costs of reentering foreign markets after a temporary withdrawal may choose to export even if this involves incurring losses in the short run. Nonetheless, domestic output will decline as export- and import-competing industries run down their inventories in response to the squeeze on corporate profitability, liquidity, and cash flow.

Even if the loss of competitiveness is not expected to be transitory, export volume will respond with a considerable lag-even if new orders react fairly promptly. ${ }^{63}$ The response of producers in the export- and import-competing sectors in this case, too, is to cut back on new production and to meet outstanding orders by running down inventories. Finally, the increase in interest rates induced by tight money may be directly responsible for some inventory decumulation.

\section{A Preliminary Assessment of the Thatcher Experiment}

No final verdict can be delivered yet on the Thatcher experiment, as it is still in progress. Whether the current depression has ultimately favorable effects on business efficiency and productivity cannot be known for some time. Nor will it be known how much permanent improvement in inflation has been achieved until the economy has recovered. Although these and other ultimate goals cannot be evaluated, we can make some preliminary assessments of the Thatcher policies and the results it has thus far produced and can offer some judgments about the future.

62. See, for example, Patrick Minford, "A Rational Expectations Model of the United Kingdom under Fixed and Floating Exchange Rates," in Karl Brunner and Allan H. Meltzer, eds., On the State of Macroeconomics, Carnegie-Rochester Conference Series on Public Policy, vol. 12 (Amsterdam: North-Holland, 1980), pp. 293-355.

63. Jürg Niehans, "The Appreciation of Sterling-Causes, Effects, and Policies," SSRC Money Study Group Discussion Paper (New York: Social Science Research Council, 1981). 
The policy has achieved three interim objectives. First, it has established the principle of announcing government plans for expenditure, taxation, and financing for a much longer span of time than has been the case in the past. In principle this could, by reducing uncertainty about the future conduct of policy, improve the informational environment within which long-term private decisions are made. This would be especially valuable if it is uncertain policies rather than other, domestic or foreign, exogenous shocks that account for most of the randomness in the behavior of the economy.

Second, policy has emphasized the importance of the allocative, structural, or supply-side effects of fiscal actions. Orthodox Keynesianism in the United Kingdom has tended to view fiscal policy almost exclusively as a means for regulating effective demand.

Third, Mrs. Thatcher has given a convincing demonstration of the powerful effect of tight monetary policy on an industrialized open economy under a floating exchange rate and with a high degree of international capital mobility. To that extent, a monetary threat has been made more credible. She certainly has ended the virtually open-ended commitment to monetary accommodation of domestic wage push that characterized much of the 1960s and 1970s.

Our analysis has led to some fundamental criticisms of the design and implementation of policy thus far. Policymakers underestimated or ignored the adverse stabilization effects that the structural policy initiatives would have. The initial increase in the value added tax, for example, hardly helped the fight against inflation; the imposition of "external financing limits" on nationalized industries, which have significant monopoly power, led them to raise prices so as to generate internal funds. There has been a failure to appreciate the changes in the nature of the transmission mechanism that take place when the exchange rate is left to the market. In these circumstances, competitiveness is the first victim in the battle against inflation, and some of the anti-inflationary gains from the sharp early appreciation of the exchange rate will be lost later as the overshooting unwinds and competitiveness is restored.

The government's design and conduct of monetary policy was based on controlling the growth rate of sterling M3. Adopting a four-year target path for this version of "money" committed the government to attempt to control, almost unconditionally, an aggregate that has proved extremely difficult to influence except by direct controls such as the corset scheme, 
which the market correctly dismisses as cosmetic, or by pronounced movements in interest rates and shifts in fiscal policy, which have proved damaging to the real economy. If nominal intermediate targets are required, conditional targets for nominal interest rates or the nominal exchange rate would be more appropriate. Specifying policy in terms of contingent rules for such variables would be especially valuable if many of the shocks that buffet the economy originate in the private sector or overseas.

To achieve its monetary targets without undue reliance on interest-rate fluctuations, the administration specified a path for the PSBR relative to GDP, which increasingly is preventing fiscal policy from playing its role as an automatic stabilizer. The problem of fiscal policy design has been exacerbated by the government's emphasis on controlling the nominal PSBR. By not adjusting the PSBR for the effect of inflation on the real value of outstanding public sector debt, the authorities greatly overestimated the magnitude of financial crowding out-the extent to which the public sector competes with the private sector for loanable funds.

The government's cash-flow rather than present-value approach to the management of its North Sea oil rents means that oil-financed tax cuts have to wait until they can be paid out of concurrent government North Sea oil receipts. The latter will not reach their permanent value until 1982-83 at the earliest. The resulting unnecessary pressure on the standard of living has put upward pressure on nominal wages. Payroll tax cuts would seem to be an efficient means for avoiding these kinds of problems. Finally, on the fiscal side, given the government's overall plans for public spending, the bias of current policy against capital formation in the public sector is damaging to long-run prospects for productivity and disinflation.

The real costs in higher unemployment and lost output for reducing inflation have been increased by the failure to complement the general nonaccommodating stance of macroeconomic policy-a threat to everyone in general and to no one in particular-with measures aimed specifically and directly at influencing wages, whether through incomes policy or by reforming the British "nonsystem" of pay bargaining. Granting public sector employees in 1979-80 an increase of 25 percent was hardly consistent with a commitment to a rate of growth of money of 7 to 11 percent. Current discussion of more efficient ways of controlling the money supply through measures such as monetary base control are unimportant relative to those institutional changes necessary to combat the inflationary inertia built into the United Kingdom labor markets. These 
include decentralized, staggered, collective bargaining procedures whose emphasis on "catching up" and on restoring or improving differentials creates a mixed wage-price and wage-wage spiral with considerable momentum. Designing incentives for individual firms and unions to make noninflationary pay settlements, for example through a tax-based incomes policy, should have higher priority than designing more efficient ways of controlling some definition of the money supply. ${ }^{64}$

The policies that created the depression in output have slowed inflation, at least for now. Most recently, wage settlements have been in singledigit figures. The depreciation of sterling since early 1981 has both permitted some improvement in margins and added to the price level. If the exchange rate now stabilizes, price inflation may slow to single digits during 1982. But the cost of improvement has been enormous. Without an incomes policy or radical reform of the pay bargaining system, a further lasting reduction in the rate of inflation is likely to require a further deflation of aggregate demand, a further fall in the level of output, and even some additional increase in unemployment.

If incomes policy is deemed politically unacceptable, practically impossible, or too costly in terms of the misallocation of resources it entails, and if labor market reform is not feasible, one alternative to further deflation might be "learning to live with" the current rate of inflation of about 10 percent. More widespread indexation of the tax and benefit system and additional widening of the portfolio of indexed public sector liabilities would be a step in that direction. Even the logic of monetarism suggests no theoretical or practical reasons for believing that the only sustainable steady rate of inflation is zero. Repeated assertion has been the only evidence given by the government for its claim that bringing down inflation is a prerequisite for lower unemployment and sustained growth. Ways such as paying interest on money can be found for minimizing the "shoe leather" costs of anticipated, steady inflation.

If the government does change to a more expansionary fiscal policy in order to restore economic expansion, it should also adjust its monetary policy. Unchanged monetary targets would risk significant crowding out, not only through the direct effect of higher interest rates, but also through

64. For examples of tax-based incomes policies see Richard Layard, "Is Incomes Policy the Answer to Unemployment?" Discussion Paper 99 (London School of Economics and Political Science, Centre for Labour Economics, 1981); and Arthur M. Okun and George L. Perry, eds., Curing Chronic Inflation (Brookings Institution, 1978). 
appreciation of the real exchange rate and a squeeze on the internationally exposed sector. To avoid this, either monetary policy would have to accommodate the fiscal expansion or the free international flow of capital would have to be suspended by exchange controls, a real interest equalization tax, or some other set of administrative or fiscal measures. Alternatively, the authorities could replace their monetary target by an exchange rate target, say by joining the European Monetary System, and use fiscal policy to raise the level of capacity utilization.

By setting anti-inflationary monetary targets and vigorously pursuing them despite the inflationary pressures of 1979-80, the government hoped to change the behavior of those who set wages and prices, making inflation more sensitive to such monetary policy announcements in the future. By selecting a monetary aggregate that proved too difficult to control and by failing to support this monetary objective with other policy actions that would help directly to bring down the rate of wage and price inflation, the credibility of such monetary policy announcements has not been enhanced; the behavior of sterling M3 has, on the contrary, become an enigma. Indeed, the spectacle of the government trying vainly to cut the PSBR in an effort to attain its ill-considered monetary targets led Sir Ian Gilmour, until recently a member of the Cabinet, to define monetarism in its current manifestation as "the uncontrollable in pursuit of the indefinable."

The government has presumably achieved anti-inflationary credibility of a more general kind. Its willingness to incur very large losses in output and employment to achieve a reduction in the rate of inflation has been established beyond reasonable doubt. This, rather than the narrower credibility of monetary targeting itself, may have created the conditions under which the future announcement and implementation of additional deflationary measures would be reflected in reductions in inflation with far smaller, if not negligible, losses of output and increases in unemployment than have occurred in the past. We are skeptical about this because we believe that it would have taken more than even a credible change in the policy regime to eliminate the momentum in the wage-price process in the United Kingdom. Time will provide the answer if the government decides to continue its deflationary monetary and fiscal policies. 


\section{Comments and Discussion}

Martin Neil Baily: This paper contains a wealth of interesting information about recent economic policy and performance in the United Kingdom. Most of the important ideas and facts are discussed, although both theory and evidence could have been marshaled more effectively to support the hypotheses advanced.

The Conservative government that took office in June 1979 inherited an economy that was in very poor shape. Double digit inflation was accelerating. The level of productivity was low relative to most of Britain's European partners. General government expenditures were extremely large, at a level that necessitated very high effective rates of taxation. Strikes and industrial unrest were a serious problem, particularly in the government-controlled industries in which workers in vital sectors found that their ability to disrupt the economy had given them tremendous monopoly power over wages. The nationalization of industries, which is supposed to increase democratic control over the economy, apparently achieves the opposite.

It is not at all clear that remedies for these problems existed that could have succeeded within the time-horizon allowed by the political constraints. Mrs. Thatcher is to be commended for seeing that major changes were needed and for having the political courage to attempt them. Willem Buiter and Marcus Miller come close to declaring Mrs. Thatcher's policies a failure only twenty-seven months after she took office. And much of her own political party is ready to do the same. The electorate gave up long ago. On the centerpiece of her program-stopping inflation-I think it is too early to render a final judgment, but there is now some evidence of improvement. It is certainly true that the costs in terms of output and unemployment of the first two years have been very high. 
Buiter and Miller analyze the events of 1979 to 1981 within a sticky wage and price framework and the basic argument about what went wrong is fairly straightforward. Contractionary monetary and fiscal policy reduced the level of nominal demand. Since wages and prices were sticky, this translated into a decline in real output, an increase in unemployment, and a moderate abatement of inflation. This is a sensible story; surely there is a substantial core of truth to it. The story of Britain in $1980-81$, like the story of the U.S. economy in 1975 , is that systematic contractionary policy does indeed reduce real output. But I would also stress, first, that the rise in the sterling exchange rate was probably not purely a result of monetary policy and, second, that both the accelerating wage-push inflation after 1978 and the second OPEC price shock in 1979 exerted upward pressure on prices and downward pressure on outputin ways I discuss below. Bad luck has compounded the effects of policy and turned what was probably a necessary recession into a ghastly depression.

On fiscal policy, the authors argue that the budget deficit, which has been of such concern to the government, in fact has been caused by the recession, and once the appropriate adjustments have been made, final policy can be shown to be slightly contractionary. The authors' analysis looks sound.

Most of the attention of the Thatcher experiment has been focused on monetary policy because of Mrs. Thatcher's monetarist convictions. Here it turns out to be very hard to read the signals correctly. That fact in itself is of importance for monetarism, which is supposed to provide a simple policy rule and a predictable outcome. Alternative measures of the nominal money stock diverged sharply. However, the real money stock, by all measures, fell in 1979-80. Nominal interest rates rose dramatically, and ex post real interest rates fell or rose, depending on what price index one uses. Because the surge in the price level was a surprise and was not expected to become a permanently higher inflation rate, ex ante expected real rates of interest were probably high.

Buiter and Miller argue that the narrow M1 measure of money is better than the broader M3 measure (used by the government in its setting of targets) and hence that the sharp deceleration of M1 growth indicates a tight policy. Frankly, I do not know how to evaluate the status of monetary policy in a simple way because the financial institutions have been changed so much. I think the key to the British experience is the surge in 
the price level. The most striking fact in table 8 is the decline in the real money stock by all measures. By refusing to accommodate the change in the price level, the government in a sense acquiesced in a very tight monetary policy.

A topic of great interest to Buiter and Miller is the role of the foreign trade sector and the exchange rate in the decline of output and employment. The value of sterling rose sharply compared with Britain's major trading partners. Since wages were also rising rapidly, the result was that the International Monetary Fund's index of relative unit labor costs for the United Kingdom was up 40 percent in 1980 over 1978. Somewhat surprisingly, this dramatic change in competitiveness did not show up very strongly in import or export volumes. There was some slight increase in the ratio of imports to GDP, and the changing position of the United Kingdom with respect to oil imports and exports had an effect. Nonoil exports were weakening, but not by that much. The mechanism that Buiter and Miller say caused the downturn works through profitability and inventories. When manufacturing in the United Kingdom became uncompetitive, firms continued to sell overseas to preserve market share in the hope that sterling would soon fall. But because their profits were squeezed, these firms cut production, cut investment, and liquidated inventories. The inventory swing in particular was quite large. Just to quibble, I would point out that inventory swings are usually very large in a business cycle downturn, even when foreign trade is not important. This would have been especially true in a tight-money recession. The authors' assertion about the importance of trade is probably correct; it almost has to be correct. But it is surprising that it does not stand out in the data.

If one accepts that the exchange rate was important, the next question is, what caused the pound to rise instead of fall as domestic wages and prices rose? Buiter and Miller agree that an increase in the world price of oil should raise the exchange rate of the United Kingdom relative to countries that are not self-sufficient in oil. But the oil shock in itself, they argue, can only explain a small part of the upward movement of sterling. Again, this is probably correct, but their discussion is fairly casual.

Their view of the exchange rate is based upon the Dornbusch overshooting model; that is, it is seen as a consequence of tight money in a sticky wage economy. The Dornbusch model, instructive though it is in many ways, does not really explain why exchange rate movements around the world seem to overshoot so drastically. For example, the pound was 
$\$ 2.39$ at the end of 1980 and has subsequently dropped as low as $\$ 1.80$. It is hard to see enough in interest rate changes or other fundamentals to cause a decline of this magnitude. This makes one suspect that the initial rise of sterling to $\$ 2.39$ was also partially a speculative swing. The loss of United Kingdom competitiveness in 1979-80 seems to have been partly a result of unwarranted confidence in British economic performance by foreign exchange traders.

The long-run trade-off between unemployment and inflation that resulted from the decline in aggregate demand has not yet been revealed. The crucial test for the Thatcher policy should be whether or not full employment can be restored with price stability. That test may never be passed or failed because of the political time-horizon.

The short-run trade-off has been adverse for a variety of reasons. First, Mrs. Thatcher inherited an accelerating inflation as the Labour government's incomes policy collapsed. Second, the shift from income taxes to value added taxes affected at least the standard consumer price index more or less by the full amount of the increase in value added taxes. Third, the price of OPEC oil increased. Fourth, the large public sector was given a massive pay increase. A substantial part, but not all, of the inflation bubble of 1979-80 was, therefore, caused by self-inflicted policy wounds. Since 1980 the slowdown in inflation is beginning to look much more encouraging. So it should, given the massive increase in unemployment. But at least the refusal to accommodate inflationary wage settlements is having an impact on the size of those settlements. This effect did not occur by any magical alteration of expectations but by the old-fashioned threat of bankruptcy and joblessness. The real question for the future is whether or not wage inflation will reaccelerate when or if full employment is restored.

My overall assessment of the Thatcher experiment differs in emphasis from that of Buiter and Miller. They are correct that there is much to criticize. It was foolish to abandon the stabilization of the real economy and to take actions that raised the price level; but the inherited situation was so bad that a very difficult economic period was inevitable. Some part of the depression was not Mrs. Thatcher's fault. Some fairly drastic measures to revive the private sector and scale down the public sector were called for.

I turn now to a question of interest for U.S. macroeconomists: to what extent does the British experiment help to decide the validity of the monetarist and rational expectations models? Thomas Sargent has re- 
cently written a fascinating exposition of his view of the Thatcher experience thus far, and I think it is worthwhile contrasting his views with those of Buiter and Miller. ${ }^{1}$

Sargent argues that Mrs. Thatcher's election did not represent a policy regime change and that it is, therefore, not surprising that the tight monetary policy that she introduced caused a decline in real output. Sargent also emphasizes the importance of the exchange rate and discusses the Dornbusch overshooting model. In many ways, therefore, the Sargent analysis agrees with the conclusions of Buiter and Miller. The big difference is that Sargent argues that with different preconditions the real costs could have been avoided. In particular, he argues that substantial budget deficits undermined confidence in the ability of the government to maintain monetary control in the future. In fact this is the key point he makes. Fiscal responsibility is essential to a regime change.

I must say my sympathy goes to Mrs. Thatcher at this point. She was told that salvation lies in strict monetary control. She followed this advice, or tried to, and was hit by a massive recession. A consequence of the recession was and is a large deficit, but she is now told that the reason her policies are not working is because of the deficit. I simply do not believe that the budget deficits pushed the public debt to the point that monetization will become inevitable. For one thing, the prospective North Sea oil tax revenue will provide the resources to service any current increases in debt.

More fundamentally, though, I do not see why irreversibility is important in the rational expectations models. Sargent's new classical model asserts that anticipated policy has no effect on real output. It says nothing about whether policies are maintained or reversed. On the contrary, anticipated stop-go policies allegedly have no effect on real output. Sargent must claim, therefore, that economic agents did not know that Mrs. Thatcher was going to begin with tight money. Why would people who had rational expectations impose upon themselves serious real costs in 1980-81 just because Mrs. Thatcher might be thrown out of office in 1984 or even in 1982 ? Moreover (a debater's point, perhaps), if the tight monetary policy had reduced prices without serious real output costs, Mrs. Thatcher would have been a heroine and the policy would certainly not have been reversed, at least in the near future. The only arguments

1. Thomas J. Sargent, "Stopping Moderate Inflation: The Methods of Poincaré and Thatcher" (University of Minnesota and Federal Reserve Bank of Minneapolis, May 1981). 
that a rational expectations economist can make about the British experience, it seems to me, are either that the tight policy was a surprise or that the recession was caused principally by exogenous shocks, for example a terms-of-trade adjustment that caused structural problems. The first of these arguments is almost absurd. The second has not yet been made, and it rather undermines the general rational expectations hypothesis that economic fluctuations are caused by unanticipated policy actions.

Finally, I consider briefly what British policy should be from now on. First, stop worrying about the deficit in the short run and avoid contractionary fiscal policy. Once the economic situation improves, a program to scale down the size of government will seem easier to accomplish. Second, stop concentrating on a single indicator of monetary policy and use information on all money stocks and interest rates to determine how tight policy is. Allow a gradual recovery of demand. Having come this far it is important to maintain the principle that unions cannot expect excessive wage increases to be validated. If that is given up now, the costs will be very high. Third, given that the government has demonstrated that ultimately it does have the power to limit wage inflation, it may be that a sensible incomes policy could help the restoration of full employment and price stability. The heavy unemployment costs of demand restraint make it worthwhile to look for better incomes policies than those of the past.

William H. Branson: The paper presents a clean and sensible analysis of the recession in the United Kingdom and its source in the monetary and fiscal policies adopted by the Thatcher government. It presents a surprising fact-that as of late 1981 the recession was an inventory sale. It shows the important influence of monetary policy on the economy through the real exchange rate along lines sketched by Dornbusch and Krugman in Brookings Papers a few years ago. ${ }^{1}$ The paper also brings together data on the recession in an exposition that will be fascinating reading for U.S. macroeconomists. The one point that I will question in this comment is the evaluation of the Thatcher experiment. The discussion seems a bit ambiguous about the criteria for evaluation. I think the jury has to remain out in this case for some time to come. In the comments that follow, I briefly discuss the analysis of the recession and then come to the evaluation of the Thatcher experiment.

The numbers on monetary policy are summarized in table 8 . The real

1. Rudiger Dornbusch and Paul Krugman, "Flexible Exchange Rates in the Short Run," BPEA, 3:1976, pp. 537-75. 
monetary base has been shrinking since 1979:3. Sterling M3 contracted in real terms from 1979:3 to 1980:2, but growth picked up by 1981 . These money growth figures may look tight by some standards, but they do not indicate lower real money growth than the United States experienced over the same period.

Another indicator of monetary tightness is real interest rates, which are summarized in table 9. If the nominal yield on twenty-year government securities is compared with the concurrent rate of increase of the retail price index, one can see negative real rates from 1979:3 to the end of 1980. Thus the data on interest rates do not indicate particularly tight money, either. Perhaps the increases in bankruptcies and liquidations shown in table 10 are better indicators of the monetary squeeze.

It is hard, on balance, to read the evidence as showing extremely tight money up to early 1981 . It may be that the perception of the public that the government intended to tighten led to an expectations-based recession.

While the exchange rate had been appreciating even before the Thatcher government, it went through an enormous real appreciation from mid-1979 to the beginning of 1981. This is shown in table 4. From 1979:2 to $1980: 4$, the nominal effective exchange rate appreciated about 15 percent. Relative unit labor costs in domestic currency went up by another 19 percent. So relative unit labor costs expressed in a common currency rose by 34 percent. The sterling appreciation in nominal terms added to an inflation running ahead of the competition. The consequence of this was the deep recession illustrated in table 1 .

Where did the recession appear in the demand categories of table 2? From 1979 to 1980 , fixed investment fell by 2 percent in real terms. The quarterly data in the bottom half of the table tell the real story, though. From a peak of $£ 21.2$ billion in $1979: 4$, real investment fell to $£ 19.0$ billion by $1981: 1$, a drop of more than 10 percent. Thus the cumulative effect of the expected money squeeze is building, even though it does not appear to be strong in the annual GNP data.

Government and private consumption have continued to increase in real terms. The annual data show exports rising a bit from 1979 to 1980 , but the quarterly data show a drop from a peak of $£ 33.9$ billion sterling in $1980: 1$ to $£ 32.3$ billion in $1980: 4$. Thus the real appreciation may have been cutting into exports by mid-1980.

The big drop in GNP has come in the inventory sellout shown in table 2. As the paper notes, this accounts for more than all of the drop 
in GNP. The explanation in the paper runs from tight money and cashflow problems to liquidation and inventory run-down, and finally production cuts and unemployment. The open-economy aspect of the inventory depletion is an important part of the picture. The increase in relative unit labor costs in the export industries, working against prices constrained by international competition, squeezes profits even more severely than in "sheltered" domestic industry. For a time, export sales are met from inventory, but eventually they begin to fall. This is consistent with the data of table 2 .

What about the outlook? Table 4 shows the beginning of the rebound in competitiveness. As of August 1981 the sterling effective exchange rate was 91.3, back to its level in 1979:3. At the same time, domestic currency unit labor costs have gone up in the United Kingdom relative to the competitors, so the loss of competitiveness arising from that source remains in the real exchange rate.

The sterling-dollar exchange rate is back to 1.82 (in September 1981). It was $\$ 2.06$ the day the Thatcher government took office. It can be seen in the exchange rate numbers that the effective exchange rate is back to its 1979:3 value, but sterling, in terms of the dollar, has moved from $\$ 2.06$ to $\$ 1.84$ from 1979:2 to $1981: 3$. This shows that the dollar has been appreciating relative to all currencies, not that sterling has been depreciating.

There remains a real appreciation of sterling, and fall in real exports and investment as of late 1981. This makes the outlook one of deepening recession into 1982 .

Finally, I turn to the evaluation of the Thatcher experiment, which I find somewhat tricky. On very narrow grounds this policy might be said to have failed because of the selection of the wrong monetary aggregate to control. One could say that the policy failed because the government tried to control an aggregate that is uncontrollable. If the policy failed on these grounds, there would not be any reason to present a long paper with an extensive discussion of unemployment and depression. One would simply show that policy used the wrong instrument. But I have the feeling that this is not the whole answer. Suppose the right monetary aggregate had been chosen?

If the point of the experiment is to show that the monetary targets will be maintained in order to make future policy more effective, it seems to me perfectly possible that a deep recession would be necessary to con- 
vince the labor market participants that policy will persist. So the existence of a deep recession would not be convincing evidence that the Thatcher experiment has failed. The very existence of the recession might be required to make it succeed.

I am a little uneasy about this definition of the Thatcher experiment and this way of deciding whether or not it has failed. I would prefer a definition that states what has been implicit: that the announcement of adherence to monetary targets would bring down the rate of inflation without causing excessive costs. The level of costs that are excessive would have to be as defined by the Thatcher government in order to avoid the trap of saying that the experiment has failed because the government fails to accept my social judgments about the cost of unemployment.

Furthermore, to be fair, one should count just those costs that occurred and that were a predictable result of the policy. If it was not predictable, one might regard the recession as the luck of the draw and not an indication that the policy has failed. Thus far the recession has come mainly in the form of a big inventory drop. With a high inventory-sales ratio and a small drop in investment spending, a large swing in inventory accumulation can occur; but that is difficult to forecast. So it is not clear how much of the present recession is a predictable result of the policy. Buiter and Miller might well not have predicted what is happening if they had, in the third quarter of 1979, made a forecast of the economy of the United Kingdom conditioned on the Thatcher policies that actually evolved.

All of this is to say that the failure of the particular model of the economy implicit in the Thatcher experiment is hard to prove, at least from this paper. It remains true that the recession has gone beyond what anyone had expected publicly. And, in my opinion, it has gone much too far. It is a fair criticism that economic performance has been dismal. But the jury is still out on the Thatcher experiment, whatever the experiment is.

\section{General Discussion}

Several discussants suggested that the 1979 oil price shock and the availability of substantial oil resources in Britain may have played a larger role in the British recession than that suggested by Buiter and Miller. Robin Marris disagreed with the view that most of the rise in the 
exchange rate is a consequence of tight money. He suggested that the size of the British oil reserves only began to be recognized after 1976, and the effect of these reserves on the sterling exchange rate was still growing at the time Mrs. Thatcher took office. Peter Kenen emphasized that even though the real income of the United Kingdom may not have been directly affected by the 1979 oil price rise, its position relative to other industrial countries that were oil importers was affected, and this could have appreciated the pound. Furthermore, the occurrence of OPEC-2 demonstrated the value of Britain's self-sufficiency, and this would have had immediate impacts on the exchange rate. Jeffrey Sachs emphasized that, although OPEC-1 and OPEC-2 posed similar stabilization problems for industrial nations, the responses of policy and labor were not the same on each occasion and have not been the same in different countries. In Britain the principal difference between the two periods is that the authorities accommodated the shock with expansionary monetary policy in 1974 , while there was less accommodation in 1980 and, consequently, a much smaller increase in inflation and a greater loss of output. Sachs further argued that the nominal wage explosion taking place when Mrs. Thatcher took office represented an even more serious supply shock than the 1979 oil price rise. Real wages rose much faster in Britain than in other major industrial countries and for that reason the recession in Britain was much more severe.

There was some disagreement about the way monetary policy is conducted in the United Kingdom, even given the government's own high priority on stopping inflation. Marris agreed with Buiter and Miller that in selecting sterling M3, the Bank of England chose the wrong monetary instrument. But he observed that whenever a monetarist policy is found not to work the monetarist conclusion is that the wrong technical tool was chosen. Nicholas Kaldor disagreed that sterling M3 was an unfortunate monetary target. While certainly not a good indicator for policy, all the other monetary alternatives are worse. In particular, while the government has only limited control over sterling M3, it has no control at all over the supply of M1. Kaldor also disagreed with the authors' contention that monetary policy was tight. While agreeing that the government intended a tight monetary policy, he pointed out that bank credit to the private sector has gone up faster under Mrs. Thatcher than it did in previous years, as shown by the fact that the money supply (M3) increased by 18 percent annually since the second quarter of 1979 , while it only 
increased at an annual rate of 11.2 percent during the previous five years. Borrowers had access to credit and did not complain. While interest rates have been higher under Mrs. Thatcher, inflationary expectations have been higher also, thus mitigating their effects.

Sachs thought the authors were disingenuous in complaining about Mrs. Thatcher's neglect of incomes policies because such policies have been thoroughly repudiated by unions and are unpopular across the political spectrum. Moreover, previous incomes policies have worked only briefly and have always been followed by price explosions. Kaldor suggested that Mrs. Thatcher has actually made a reversal on incomes policy by announcing that public-sector employees-who constitute onethird of all employees-can receive wage increases of only $71 / 2$ percent this year and 4 percent next year. Given the size of the public sector, this will exert substantial pressure on private wage settlements. Marcus Miller agreed that the public-sector pay proposal amounts to back-door incomes policy, thus increasing the likelihood that such a policy may become politically feasible. He also noted that the political system may be evolving in such a way that the opposition to such policies by both labor unions and conservative politicians will be less important than it has been.

In assessing the overall success of the Thatcher experiment, Kaldor remarked that the program could only be considered successful if economic growth and high employment are restored and accompanied by much less inflation than there would have been otherwise. So far there is no evidence of this or, indeed, of any recovery in the near future, though the cost of the policies has been the largest drop in British manufacturing output ever observed. Sachs argued that Mrs. Thatcher's policies have to be evaluated against the problems of the oil price shock and wage explosion. These and the nonaccommodative response to them are the major causes of the British recession. The policy should be credited with avoiding an acceleration of inflation like the one that accompanied the accommodation of the OPEC-1 shock.

James Tobin noted that the Thatcher program is as close as we are likely to come to an experiment testing the Fellner strategy of the credible threat. Tobin said that, as a social scientist, he would not like to interrupt this experiment now before its efficacy and cost have been tested. Moreover, it would seem foolish to stop a program that might be on the verge of success after the huge costs incurred over the past two years. Tobin then noted an essential difference between the disinflation strategies pur- 
sued in the United States and the United Kingdom. Although Mrs. Thatcher has been quite explicit in publicly announcing the costs that her economic policies would entail if the private sector persisted in inflationary wage and price behavior, the president of the United States has left to Murray Weidenbaum and Paul Volcker the job of explaining the unpleasant consequences that his policies will have if inflation does not slow. U.S. policy is missing the clear articulation of the threat that it entails and consequently is much less effective as a Fellner strategy. 